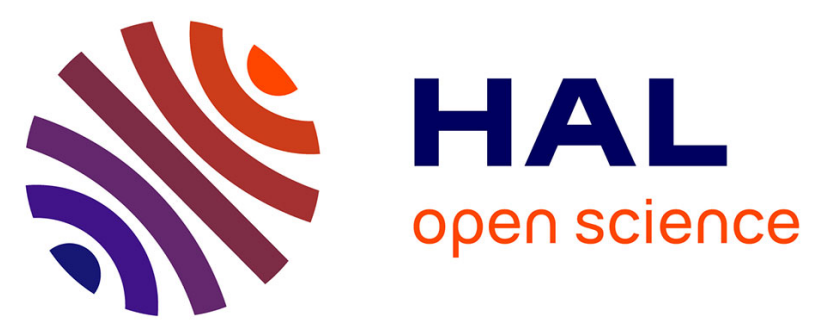

\title{
Characterizing fluxes of trace metals related to dissolved and suspended matter during a storm event: application to a karst aquifer using trace metals and rare earth elements as provenance indicators
}

Cybèle Cholet, Marc Steinmann, Jean-Baptiste Charlier, Sophie Denimal

\section{To cite this version:}

Cybèle Cholet, Marc Steinmann, Jean-Baptiste Charlier, Sophie Denimal. Characterizing fluxes of trace metals related to dissolved and suspended matter during a storm event: application to a karst aquifer using trace metals and rare earth elements as provenance indicators. Hydrogeology Journal, 2019, 27 (1), pp.305-319. hal-02019559

\author{
HAL Id: hal-02019559 \\ https://hal.science/hal-02019559
}

Submitted on 27 May 2021

HAL is a multi-disciplinary open access archive for the deposit and dissemination of scientific research documents, whether they are published or not. The documents may come from teaching and research institutions in France or abroad, or from public or private research centers.
L'archive ouverte pluridisciplinaire HAL, est destinée au dépôt et à la diffusion de documents scientifiques de niveau recherche, publiés ou non, émanant des établissements d'enseignement et de recherche français ou étrangers, des laboratoires publics ou privés. 
Characterizing fluxes of trace metals related to dissolved and suspended matter during a storm event: application to a karst aquifer using trace metals and rare earth elements as provenance indicators

Caractérisation des flux des métaux en éléments tracés associés à la matière dissoute et en suspension au cours d'une crue événement orageux: application à un aquifère karstique en utilisant les éléments traces des métaux traces et lesde-terres rares comme indicateurs de provenance Caracterización de los flujos de metales traza relacionados con la materia disuelta y en suspensión durante un evento de tormenta: aplicación a un acuífero kárstico usando metales traza y elementos de tierras raras como indicadores de procedencia

暴雨事件期间与溶解物质和悬浮物质相关的微量金属的通量 特征描述:使用痕量金属和稀土元素作为出处指标应用于岩溶 含水层

Caracterização dos fluxos de metais traços relacionados ao material dissolvido e em suspensão durante eventos de tempestade: aplicação em um aquífero cárstico usando metais traços e elementos de terras raras como indicadores de proveniência

Cybèle Cholet, 1,2

Marc Steinmann, 1 困

Emailmarc.steinmann@univ-fcomte.fr

Jean-Baptiste Charlier, 2

Sophie Denimal, 1

${ }^{1}$ Chrono-Environnement, UMR 6249 UBFC/CNRS, University of Burgundy Franche-

Comté, 25000 Besançon, France

2 BRGM, University of Montpellier, 1039 rue de Pinville, 34000 Montpellier, France 
The origin of suspended matter and colloids in karst aquifers during storm events is not well understood in spite of their potentially important role in the transport of poorly soluble inorganic, organic, and microbiological pollutants. This work aims to characterize the fluxes of trace metals related to dissolved and suspended matter during a storm event at the spring of a karst aquifer in the Jura Mountains in France that is mainly recharged by diffuse infiltration. Various natural tracers, including rare earth elements (REE), were used to identify the origin of the contributing dissolved and suspended fractions. The storm event was characterized by the temporally delayed arrival of two different fractions of suspended particulate matter (SPM). A first SPM peak corresponded to autochthonous conduit sediment mobilized by a piston effect at the beginning of the event. A second SPM peak, related to the arrival of allochthonous soil particulates, was characterized by elevated turbidity and high concentrations of $\mathrm{K}, \mathrm{Al}, \mathrm{Fe}$, and $\mathrm{Mn}$. In the dissolved fraction, this second SPM peak was accompanied by various poorly soluble trace elements, which were interpreted by the presence of nanoparticles and colloids (NPCs). The REE distribution patterns demonstrated that both the NPCs and the SPM were derived from soil particles whatever the storm stage. This suggests that the SPM of the first stage was reworked cave sediment from previous storms composed of residual clays and soil particles, which excludes authigenic precipitates (such as Fe-Mn oxyhydroxides and speleothems) as a significant source for autochthonous sediments.

\section{Résumé}

L'origine de la matière suspendue et des colloïdes dans les aquifères karstiques au cours d'événements orageux des crues; n'est- pas bien comprise malgré leur rôle potentiellement important dans le transport de polluants inorganiques; -et organiques,- peu solubles et polluants microbiologiques. Ce travail vise à caractériser les flux des éléments métalliques en trace liés à la matière dissoute et en suspension lors d'une crue à l'exutoire d'un aquifère karstique dans les montagnes du Jura en France, qui est- principalement rechargé par une-infiltration diffuse. Différents traceurs naturels, y compris les éléments-des-terres rares (ETR), ont été utilisés pour identifier l'origine des fractions dissoutes et en suspension. L'événement orageux oecasionnant une La crue a été caractérisée par une arrivée différée dans le temps de deux fractions différentes de matières-de partieules-en suspension (MPSMES). Un premier pic de MPSMES correspondait au sédiment endogène du conduit mobilisé par un effet piston au début de l'événement. Un second pic de MPS MES, associé à l'arrivée de particules exogènes, était caractérisé par une turbidité élevée et des concentrations élevées en $\mathrm{K}, \mathrm{Al}, \mathrm{Fe}$ et Mn. Dans la fraction dissoute, le second pic de MESMPS était accompagné par différents éléments traces peu solubles, ce qui a été interprété par la présence de nanoparticules et de colloïdes (NPCs). Les modalités de distribution des ETR MES montrent que les NPCs et-MPS MES proviennent tous les deux de particules de sol quel que soit le stade de l'événement. Cela suggère que ta MPS les MES au début de l'événement provientnent de la remobilisation des sédiments déposés lors de crues précédentes d'événements orageux précédents dans les eavités et, composés d'argiles résiduelles et de particules de sol, ce qui exclut des précipités endogènes (tels que des oxyhydroxydes de Fe-Mn et des spéléothèmes) comme une source significative de sédiments autochtones.

\section{Resumen}

El origen de la materia en suspensión y los coloides en los acuíferos kársticos durante los eventos de tormentas no está bien conocido a pesar de su papel potencialmente importante en el transporte de contaminantes inorgánicos, orgánicos y microbiológicos poco solubles. El objetivo de este trabajo es caracterizar los flujos de metales traza relacionados con la materia disuelta y en suspensión durante un evento de tormenta en el manantial de un acuífero kárstico en Jura Mountains en Francia, que se recarga principalmente por infiltración difusa. Se usaron varios trazadores naturales, incluidos los elementos de tierras raras (REE), para identificar el origen de las contribuciones de las fracciones disueltas y en suspensión. El evento de tormenta se caracterizó por la llegada temporalmente retrasada de dos fracciones diferentes de materia particulada en suspensión (SPM). Un primer pico de SPM correspondió a un sedimento de autóctono del conducto movilizado por un efecto de pistón al comienzo del evento. Un segundo pico de SPM, relacionado con la llegada de partículas de suelo alóctono, se caracterizó por una elevada turbidez y altas concentraciones de K, Al, Fe, y Mn. En la fracción disuelta, este segundo pico de SPM fue acompañado por varios oligoelementos poco solubles, que fueron interpretados por la presencia de nanopartículas y coloides (NPC). Los patrones de distribución REE demostraron que tanto los NPC como el SPM se derivaron de las partículas del suelo cualquiera que sea la etapa de la tormenta. Esto sugiere que el SPM de la primera etapa fue un sedimento retrabajado de tormentas previas compuesto de arcillas residuales y partículas de 
suelo, que excluye los precipitados autigénicos (como oxihidróxidos de Fe-Mn y espeleotemas) como fuente significativa de sedimentos autóctonos.

\section{摘要}

尽管岩溶含水层中的悬浮物质和胶体在溶解很差的无机、有机及微生物污染物搬运中可能扮演非常重要的角 色,但暴雨事件期间岩溶含水层中的悬浮物质和胶体成因还不是了解的很清楚。本研究工作目的就是描述法国 Jura山脉中一个主要有弥散入渗不及的岩溶含水层泉处暴雨事件期间与溶解物质和悬浮物质相关的微量金属 通量的特征。各种天然示踪剂包括稀土元素用来确定溶解和悬浮物质的成因。暴雨事件的特征就是悬浮微粒物 质两种不同部分的延迟达到。第一个悬浮微粒物质高峰相当于原地的通道沉积物,这个原地的通道沉积物由事 件开始时的活塞效应激活。第二个悬浮微粒物质高峰与外来的土壤微粒相关,呈现的特征是浊度升高, 以及 $\mathrm{K}$, $\mathrm{Al}, \mathrm{Fe}$ 和 $\mathrm{Mn}$ 浓度升高。在溶解物质中,第二个悬浮微粒物质高峰伴随着各种溶解很差的微量元素,这些微量元素 可通过纳米粒子和胶体的存在得到解译。稀土元素分布模式显示,无论在暴雨的什么阶段,纳米粒子和悬浮微粒 物质都来源于土壤粒子。这表明第一阶段的悬浮微粒物质由先前的包含残余黏土和土壤颗粒的暴雨再沉积成 洞穴沉积物,这些残余黏土和土壤颗粒不包括作为原地沉积物重要来源的自生沉淀物(如铁锰氢氧化合物及洞 穴堆积物)。

\section{Resumo}

A origem de materiais em suspensão e coloides em aquíferos cársticos durante eventos de tempestade não é muito conhecida, apesar do seu papel potencialmente importante no transporte de poluentes inorgânicos, orgânicos e microbiológicos pouco solúveis. Este trabalho tem como objetivo principal a caracterização dos fluxos de metais traços relacionados com a matéria dissolvida e em suspensão durante eventos de tempestade em uma nascente em um aquífero cárstico nas Montanhas Jura, na França, que é principalmente recarregada por infiltração difusa. Vários traçadores naturais, incluindo elementos de terras raras (ETR) foram usados para identificar a origem das frações contribuintes dissolvidas e em suspensão. Eventos de tempestade são caracterizados pela chegada temporal de duas diferentes frações de material particulado em suspensão (MPS). O primeiro pico de MPS corresponde a um sedimento de conduto autóctone mobilizado pelo efeito pistão no inicio do evento. Um segundo pico do MPS, relacionado à chegada de partículas de solo alóctone, foi caracterizada pela turbidez elevada e altas concentrações de K, Al, Fe e Mn. Na fração dissolvida, o segundo pico de MPS foi acompanhado por vários oligoelementos pouco solúveis, que podem ser interpretados pela presença de nanopartículas e coloides (NPCs). Os padrões de distribuição dos ETR demonstraram que tantos os NPCs quanto o MPS são provenientes das partículas do solo, independentemente do estágio da tempestade. Isto sugere que o MPS do primeiro estágio foi retrabalhado em sedimentos de caverna em tempestades anteriores compostas por argilas residuais e partículas de solo, o que exclui precipitados autigênicos (como os oxi-hidróxidos de Fe-Mn e espelotemas) como fonte significativa de sedimentos autóctones.

\section{Keywords}

\section{Karst}

France

Hydrochemistry

Suspended load

Natural tracer

Electronic supplementary material

The online version of this article ( https://doi.org/10.1007/s10040-018-1859-2 ) contains supplementary material, which is available to authorized users.

\section{Introduction}

Karst aquifers are an important drinking water resource. Almost $10 \%$ of the Earth's surface is covered by karstified limestones, exceeding 30\% in some European countries (Ford and Williams 2007; Chen et al. 2017). The importance of karst aquifers is growing because increasing desertification and increasing water demand in semi-arid areas lead 
to intensified exploitation (Drew and Hötzl 1999; Andreo et al. 2006).

Karst aquifers are a highly vulnerable water resource due to the absence of deep filtering soils, and the presence of preferential pathways in the infiltration zone. Large conduits in the underground network result in rapid water flow during storms (White 2002; Goldscheider and Drew 2007). These fast flows mobilize allochthonous particles by soil erosion in the recharge area and autochthonous particles by reworking of sediment inside the conduit network, leading to high turbidity peaks and elevated concentrations of suspended particulate matter (SPM), and nanoparticles and colloids (NPCs; Mahler and Lynch 1999; Shevenell and McCarthy 2002; Amraoui et al. 2003; Massei et al. 2006; Fournier et al. 2009; Herman et al. 2012). Residual clays from limestone dissolution may occur simultaneously in the autochthonous and allochthonous pools, because they may be derived from limestone dissolution in the underground or from surface soil, which typically contains a considerable fraction of residual clays integrated during soil formation (Ford and Williams 2007; Brioschi et al. 2013). However, from a geochemical and mineralogical point of view, both types of residual clay are identical and this paper will, therefore, only differentiate between autochthonous and allochthonous SPM and NPCs.

Karst waters are characterized by circumneutral to basic $\mathrm{pH}$ values. Many organic and inorganic pollutants are not or only poorly soluble under these conditions and therefore not transported in dissolved form, but sorbed on SPM and NPCs (Vesper et al. 2001; Vesper and White 2003a; Hartland et al. 2012; Morasch 2013). The occurrence of bacteria in karst springs is similarly often correlated with SPM peaks (Ryan and Meiman 1996; Mahler et al. 2000; DussartBaptista et al. 2003; Pronk et al. 2006, 2007, 2009; Laroche et al. 2010), demonstrating that the SPM fraction is not only important for the transport of chemicals but also of bacterial pollution. Storm events with SPM peaks are therefore the "hot moments" (McClain et al. 2003) for pollution transfer in karst systems.

Several studies have investigated chemical and isotopic signatures of karstic springs during storms at high temporal resolution (Frederickson and Criss 1999; Lee and Krothe 2001, 2003; Aquilina et al. 2006; Mudarra et al. 2011; Charlier et al. 2012; Caetano Bicalho et al. 2012). They showed that chemical spring hydrograph separation may help to characterize water origin, to differentiate between pre-event and event water, and to identify the contributions of the different aquifer compartments (epikarst, unsaturated and saturated zones). However, most hydrochemical studies on storm events in karst systems were based on filtered samples, in spite of the potentially important role of the SPM fraction. This shortcoming is probably due to analytical difficulties and costs and, as a consequence, only little is known on the quantitative partitioning over time between dissolved and SPM fractions for chemical transfers during storm events.

The origin of the SPM and NPC load in karst systems, i.e. autochthonous vs. allochthonous, is difficult to determine. Pronk et al. (2007) used continuous in-situ monitoring of particle-size distribution and showed for an aquifer fed by a sinking stream that autochthonous SPM consisted of a broad particle mixture of very variable size, whereas allochthonous particles were smaller and better sorted with a dominant particle diameter of 1-2 $\mu \mathrm{m}$. Most mineralogical and isotopic approaches are, contrary to particle-size distribution, not applicable in situ at high temporal resolution for technical reasons (multitude of samples, limited sample volumes etc.). Mineralogical and isotopic methods are, therefore, inappropriate to identify rapid changes of SPM and NPC composition during storms. Consequently, new tracers are needed. Such a tracer must not only be applicable at high frequency, but also be operational with the limited sample volume of automatic samplers. Rare earth elements (REE) have been used in the past to identify specific NPC and SPM sources in rivers (Tepe and Bau 2014, 2015). For karst terrains it was shown that the bedrock and the individual soil horizons had specific REE distribution patterns, depending on mineralogy and redox conditions during soil formation (Laveuf et al. 2008, 2012; Brioschi et al. 2013). In a recent study of karst springs in the Alps it was shown that the REE concentrations increased during recharge events with distribution patterns similar to average upper continental crust during peak flow (Filippini et al. 2018). In karst caves it was shown that stalactites had characteristic REE signatures, which were distinctly different from local limestone and overlying soil, due to various fractionation mechanisms occurring during water/soil interaction, groundwater seepage and stalactite precipitation (Zhou et al. 2008, 2012; Bourdin et al. 2011). The different REE distribution patterns of surface soils, limestone bedrock and authigenic precipitates may thus make the REE a suitable tool to distinguish between autochthonous and allochthonous NPCs and SPM in karst systems. The interest of REE over other fingerprinting methods (e.g. mineralogical or isotopic approaches) is that they can be analyzed by inductively coupled plasma mass spectrometry (ICP-MS) jointly with other trace metals without specific preparation or additional sample volumes, allowing monitoring at high temporal resolution and without extra costs.

The aim of the present paper is to quantify chemical fluxes over time related to dissolved transport and SPM during 
a storm event in a karst aquifer, using various natural tracers. First, the course of the storm is analyzed on the basis of classical hydrochemical tracers, i.e. major elements and organic carbon of filtered samples. This scheme will be completed with trace metal and REE data for the filtered and the SPM fraction. The origin of the NPC and SPM will be discussed, notably by comparing their REE distribution patterns. Lastly, the metal fluxes related to the different fractions will be quantified and discussed.

\section{Study site and methods}

\section{Study site, field sampling and monitoring}

The study site was the Dahon karst spring in the Jura Mountains in eastern France, close to the village of Epenoy at an elevation of $720 \mathrm{~m}$ above sea level (Fig. 1). It is a small perennial spring used for drinking water supply with an average flow of $15 \mathrm{~L} / \mathrm{s}$ (ranging between 0.4 and $200 \mathrm{~L} / \mathrm{s}$ ). Water $\mathrm{pH}$ varied between 7.1 and 7.7. The site is located at the foot of a 30-m-high cliff in a small blind valley cut into a plateau of tabular Upper Jurassic limestone (Kimmeridgian), which seems delimited at its base by a laterally continuous, about 1-2-m thick clay layer acting as aquitard (Cholet 2017). The recharge area on the plateau of about $1 \mathrm{~km}^{2}$ is mainly covered by grassland and some forest. Swallow holes and large dolines are absent, indicating that the system is mainly recharged by diffuse infiltration. The mean annual precipitation is about $1,400-1,500 \mathrm{~mm}$ and the mean annual temperature $9.5^{\circ} \mathrm{C}$ (Vermot-Desroches 2015).

\section{Fig. 1}

Location of the Dahon spring and the En-Versennes cave in the Jura Mountains

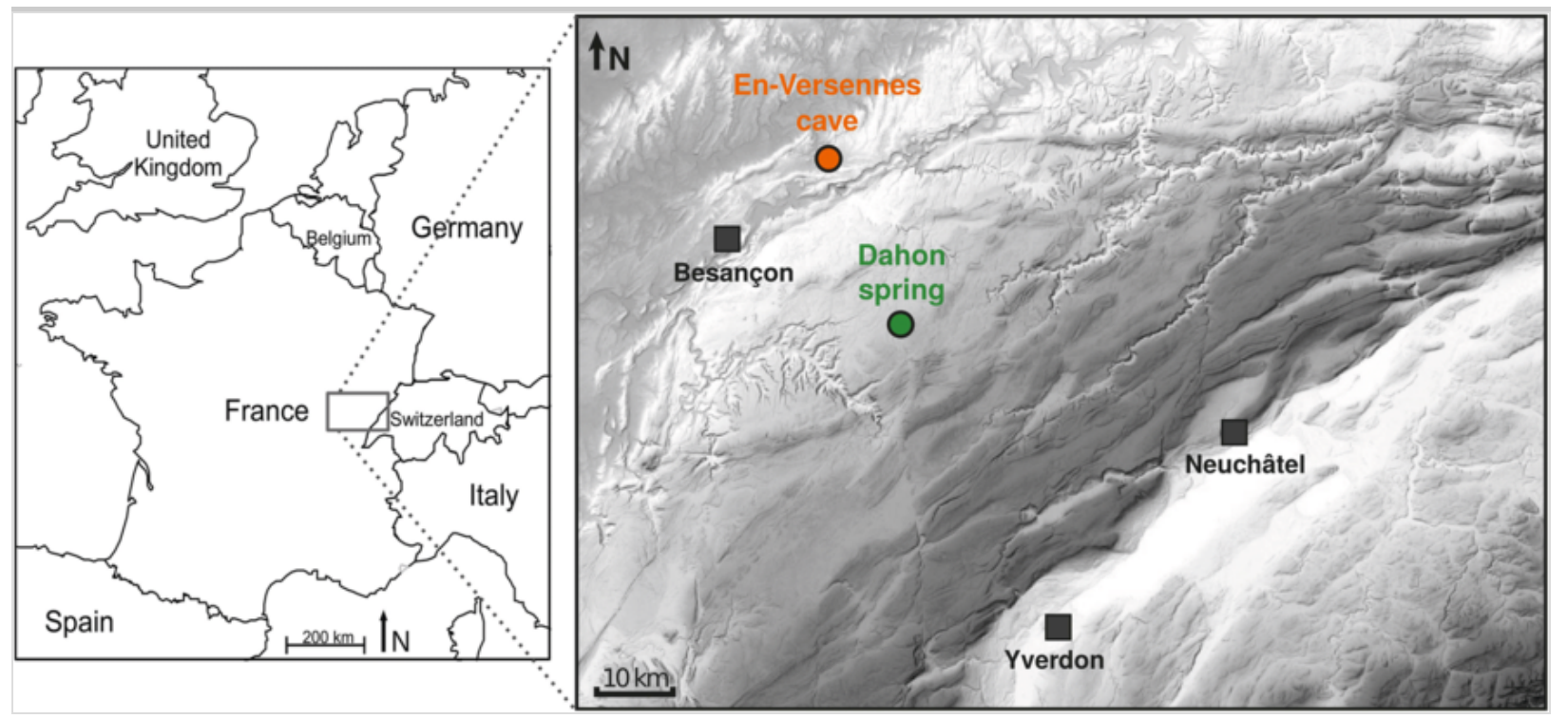

The storm event of the 4 November 2014 was triggered by a continuous rainfall event of $46 \mathrm{~mm}$ within $30 \mathrm{~h}$ after 13 days without rain (Fig. 2). Storm monitoring at 2-h intervals began on November 3 at 4 pm until November 7 at noon (47 samples), and was continued at 3-h intervals until November 10 at 9 am (23 samples). However, in the following assessment, only the samples from November 4, 10 am to November 6, 9 am will be used (23 samples, Table 1). Water samples were collected with an automatic sampler (Teledyne ISCO) with 24 HDPE bottles previously cleaned with $\mathrm{HCl}$-acidified ultrapure water (Millipore Elix-Synergy). For rainfall, hourly data of the METEO France weather station of Epenoy were used, located $0.7 \mathrm{~km}$ E of the experimental site. Water level, water temperature and electrical conductivity were monitored at 15-min intervals with a CTD probe (OTT Hydromet), and turbidity with a Ggun FL-30 field fluorimeter (Albillia Co.) at the same frequency.

\section{Fig. 2}

Evolution of rainfall, discharge (Q), electrical conductivity (EC), and various chemical parameters of $0.22-\mu \mathrm{m}$ filtered samples (in blue) during the storm event, together with turbidity and SPM load (in red) 


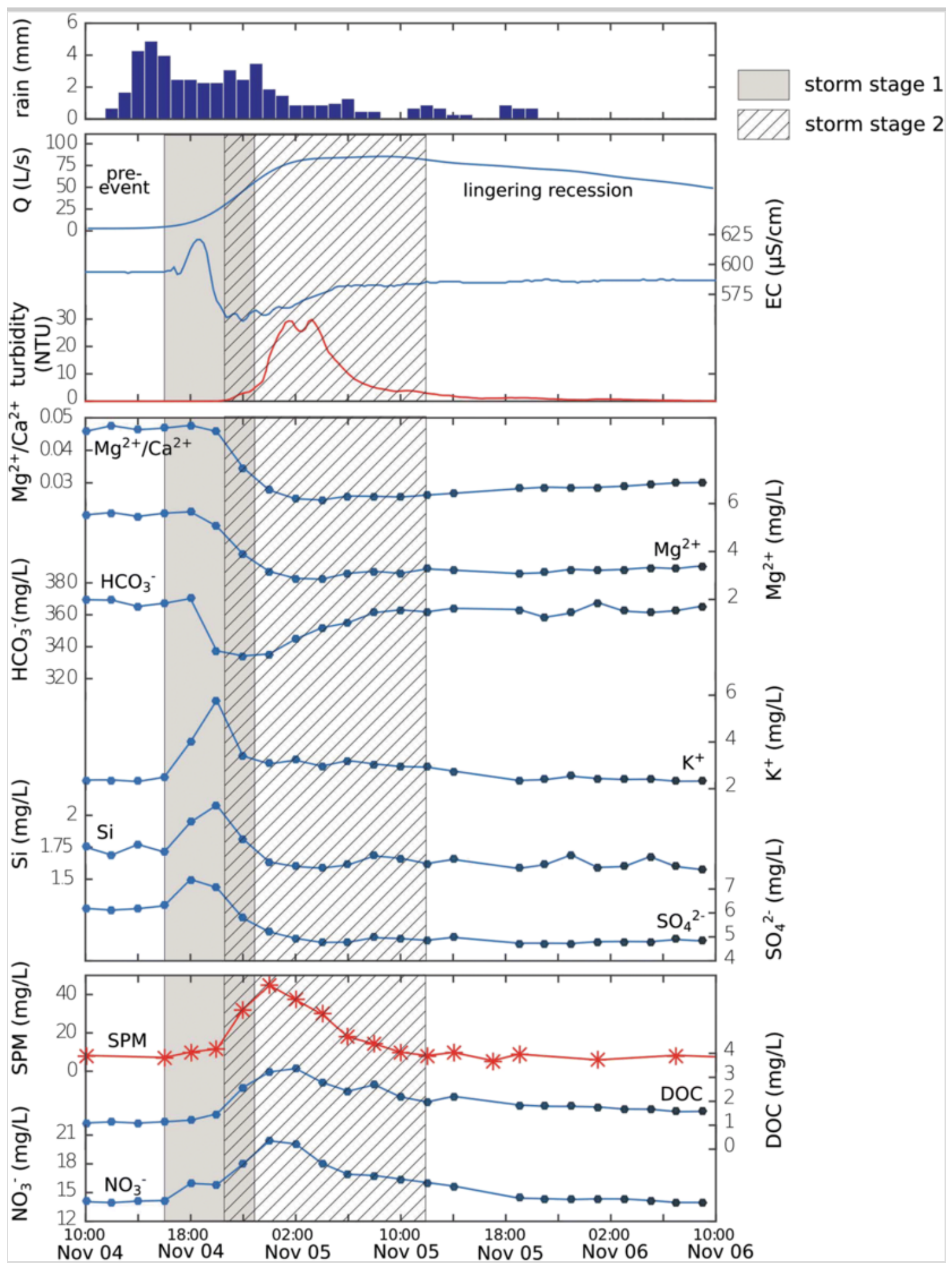

Table 1

Physico-chemical parameters of the flood event, together with the major element and the organic carbon concentrations of the $<0.22$ fractions

\begin{tabular}{|c|c|c|c|c|c|c|c|c|c|c|c|c|}
\hline \multirow{2}{*}{$\begin{array}{c}\text { Sampling } \\
\text { time }\end{array}$} & $\begin{array}{l}\text { Flow } \\
\text { rate }\end{array}$ & EC & Turbidity & DOC & $\mathrm{HCO}_{3}^{-}$ & $\mathrm{Cl}^{-}$ & $\mathrm{NO}_{3}^{-}$ & $\mathrm{SO}_{4}{ }^{2-}$ & $\mathrm{Ca}^{2+}$ & $\mathbf{K}^{+}$ & $\mathrm{Mg}^{2+}$ & $\mathbf{N a}$ \\
\hline & {$[\mathbf{L} / \mathbf{s}]$} & {$[\mu \mathrm{S} / \mathbf{c m}]$} & [NTU] & {$[\mathrm{mg} / \mathrm{L}]$} & {$[\mathrm{mg} / \mathrm{L}]$} & {$[\mathrm{mg} / \mathrm{L}]$} & {$[\mathrm{mg} / \mathrm{L}]$} & {$[\mathrm{mg} / \mathrm{L}]$} & {$[\mathrm{mg} / \mathrm{L}]$} & {$[\mathrm{mg} / \mathrm{L}]$} & {$[\mathrm{mg} / \mathrm{L}]$} & {$[\mathrm{mg} /$} \\
\hline $\begin{array}{l}\text { Analytical } \\
\text { method }\end{array}$ & & & & $\mathrm{CC}$ & titr & IC & IC & IC & $\begin{array}{l}\text { ICP } \\
\text { AES }\end{array}$ & $\begin{array}{l}\text { ICP } \\
\text { AES }\end{array}$ & $\begin{array}{l}\text { ICP } \\
\text { AES }\end{array}$ & $\begin{array}{l}\text { ICP } \\
\text { AES }\end{array}$ \\
\hline
\end{tabular}




\begin{tabular}{|c|c|c|c|c|c|c|c|c|c|c|c|c|}
\hline \multirow{2}{*}{$\begin{array}{l}\text { Sampling } \\
\text { time }\end{array}$} & $\begin{array}{l}\text { Flow } \\
\text { rate }\end{array}$ & EC & Turbidity & DOC & $\mathrm{HCO}_{3}^{-}$ & $\mathrm{Cl}^{-}$ & $\mathrm{NO}_{3}^{-}$ & $\mathrm{SO}_{4}^{2-}$ & $\mathrm{Ca}^{2+}$ & $\mathbf{K}^{+}$ & $\mathrm{Mg}^{2+}$ & $\mathrm{Na}$ \\
\hline & {$[\mathrm{L} / \mathrm{s}]$} & {$[\mu \mathrm{S} / \mathrm{cm}]$} & [NTU] & {$[\mathbf{m g} / \mathbf{L}]$} & {$[\mathrm{mg} / \mathrm{L}]$} & {$[\mathrm{mg} / \mathrm{L}]$} & {$[\mathrm{mg} / \mathrm{L}]$} & {$[\mathrm{mg} / \mathrm{L}]$} & {$[\mathrm{mg} / \mathrm{L}]$} & {$[\mathrm{mg} / \mathrm{L}]$} & {$[\mathrm{mg} / \mathrm{L}]$} & {$[\mathrm{mg}]$} \\
\hline $\begin{array}{l}2014-11-04 \\
10: 00: 00\end{array}$ & 2.7 & 594 & 0 & 1.10 & 369 & 3.83 & 14.1 & 6.19 & 121 & 2.37 & 5.53 & 2.04 \\
\hline $\begin{array}{l}2014-11-04 \\
12: 00: 00\end{array}$ & 2.8 & 594 & 0 & 1.14 & 369 & 3.81 & 14.0 & 6.12 & 118 & 2.38 & 5.63 & 2.03 \\
\hline $\begin{array}{l}\text { 2014-11-04 } \\
14: 00: 00\end{array}$ & 2.9 & 594 & 0 & 1.09 & 365 & 3.85 & 14.1 & 6.18 & 118 & 2.31 & 5.47 & 2.01 \\
\hline $\begin{array}{l}2014-11-04 \\
16: 00: 00\end{array}$ & 4.3 & 594 & 0 & 1.15 & 367 & 3.96 & 14.2 & 6.30 & 120 & 2.49 & 5.60 & 2.13 \\
\hline $\begin{array}{l}2014-11-04 \\
18: 00: 00\end{array}$ & 8.1 & 613 & 0 & 1.21 & 370 & 6.50 & 16.0 & 7.40 & 119 & 4.00 & 5.66 & 3.45 \\
\hline $\begin{array}{l}2014-11-04 \\
20: 00: 00\end{array}$ & 22.3 & 570 & 0 & 1.48 & 337 & 7.12 & 15.8 & 7.06 & 110 & 5.78 & 5.05 & 4.10 \\
\hline $\begin{array}{l}2014-11-04 \\
22: 00: 00\end{array}$ & 45.6 & 553 & 3 & 2.58 & 334 & 4.03 & 18.0 & 5.78 & 112 & 3.40 & 3.89 & 2.64 \\
\hline $\begin{array}{l}\text { 2014-11-05 } \\
\text { 00:00:00 }\end{array}$ & 68.7 & 559 & 16 & 3.23 & 336 & 3.35 & 20.4 & 5.21 & 114 & 3.06 & 3.17 & 2.26 \\
\hline $\begin{array}{l}\text { 2014-11-05 } \\
02: 00: 00\end{array}$ & 81.1 & 567 & 27 & 3.37 & 345 & 3.11 & 20.1 & 4.94 & 115 & 3.22 & 2.88 & 1.81 \\
\hline $\begin{array}{l}\text { 2014-11-05 } \\
04: 00: 00\end{array}$ & 83.7 & 576 & 24 & 2.79 & 352 & 2.69 & 18.0 & 4.77 & 115 & 2.97 & 2.85 & 1.59 \\
\hline $\begin{array}{l}\text { 2014-11-05 } \\
06: 00: 00\end{array}$ & 83.9 & 583 & 10 & 2.42 & 355 & 2.62 & 16.9 & 4.78 & 119 & 3.20 & 3.09 & 1.61 \\
\hline $\begin{array}{l}\text { 2014-11-05 } \\
08: 00: 00\end{array}$ & 85.8 & 583 & 5 & 2.69 & 361 & 2.59 & 16.8 & 4.97 & 123 & 3.06 & 3.17 & 1.59 \\
\hline $\begin{array}{l}2014-11-05 \\
10: 00: 00\end{array}$ & 85.1 & 583 & 4 & 2.18 & 363 & 2.62 & 16.4 & 4.93 & 120 & 2.95 & 3.09 & 1.60 \\
\hline $\begin{array}{l}2014-11-05 \\
12: 00: 00\end{array}$ & 81.6 & 586 & 3 & 1.97 & 362 & 2.59 & 16.1 & 4.86 & 125 & 2.92 & 3.27 & 1.64 \\
\hline $\begin{array}{l}\text { 2014-11-05 } \\
14: 00: 00\end{array}$ & 77.6 & 586 & 2 & 2.21 & 364 & 2.62 & 15.7 & 4.98 & 120 & 2.76 & 3.22 & 1.57 \\
\hline $\begin{array}{l}\text { 2014-11-05 } \\
19: 00: 00\end{array}$ & 72.7 & 586 & 1 & 1.85 & 363 & 2.39 & 14.4 & 4.74 & 109 & 2.35 & 3.08 & 1.52 \\
\hline $\begin{array}{l}\text { 2014-11-05 } \\
21: 00: 00\end{array}$ & 70.5 & 588 & 1 & 1.79 & 358 & 2.40 & 14.4 & 4.74 & 109 & 2.39 & 3.12 & 1.55 \\
\hline $\begin{array}{l}2014-11-05 \\
23: 00: 00\end{array}$ & 69.3 & 586 & 1 & 1.79 & 361 & 2.42 & 14.3 & 4.73 & 114 & 2.53 & 3.26 & 1.63 \\
\hline $\begin{array}{l}\text { 2014-11-06 } \\
01: 00: 00\end{array}$ & 65.1 & 586 & 1 & 1.77 & 368 & 2.39 & 14.4 & 4.80 & 112 & 2.44 & 3.21 & 1.59 \\
\hline $\begin{array}{l}\text { 2014-11-06 } \\
03: 00: 00\end{array}$ & 61.2 & 587 & 1 & 1.68 & 362 & 2.42 & 14.3 & 4.81 & 112 & 2.40 & 3.25 & 1.61 \\
\hline $\begin{array}{l}\text { 2014-11-06 } \\
\text { 05:00:00 }\end{array}$ & 57.8 & 587 & 0 & 1.67 & 361 & 2.40 & 14.2 & 4.80 & 113 & 2.41 & 3.33 & 1.57 \\
\hline $\begin{array}{l}\text { 2014-11-06 } \\
07: 00: 00\end{array}$ & 55.2 & 587 & 0 & 1.57 & 363 & 2.36 & 14.0 & 4.89 & 110 & 2.32 & 3.29 & 1.55 \\
\hline $\begin{array}{l}\text { 2014-11-06 } \\
\text { 09:00:00 }\end{array}$ & 50.6 & 587 & 0 & 1.58 & 366 & 2.40 & 14.0 & 4.83 & 113 & 2.33 & 3.41 & 1.59 \\
\hline
\end{tabular}

titr acidic titration; $C C$ catalytic combustion; IC ion chromatography; ICP AES inductively coupled plasma atomic emission sper

The volume of pre-event water-defined as the water initially stored in the system and drained by piston-type flows at the beginning of the storm event-was calculated by integrating discharge time series between the beginning of increasing discharge and the beginning of decreasing electrical conductivity (corresponding to the arrival of event water). Pre-event water was expressed as percentage of the total storm water volume. For the evaluation of the 
partitioning of trace metals between the dissolved and the SPM fractions, total fluxes were integrated over the entire storm event, using for each sampling interval the chemical composition of the corresponding $<0.22$ and $>0.22-\mu \mathrm{m}$ fractions, the duration of the interval, and the flow rates given in Table 1.

In order to compare spring water chemistry with potential elemental sources, local limestone, limestone interbeds and soils, as well as stalactites and authigenic seep deposits were sampled. Soil and rock samples were collected in the direct vicinity of the study site. Soil samples included pasture soil, forest soil, and the infill of a karst pocket. Rock samples were taken from massif limestone beds and marly limestone interbeds. For all soil and rock samples, three subsamples were taken and analyzed separately. The conduits of the karst system of the Dahon spring are not accessible. Stalactites and authigenic seep deposits were therefore sampled in the accessible karst cave of EnVersennes near the village of Fontenotte, about $25 \mathrm{~km}$ to the north of the Dahon spring (Cholet et al. 2017; Cholet 2017); however, the lithology of the limestones and the soil cover are comparable for both sites (Cholet 2017). Brownish Fe-rich stalactites were sampled from the cave ceiling, whereas the black Mn-rich seep deposits occurred next to the cave stream within the epiphreatic zone. As for soils and rocks, three subsamples were taken for each deposit type and analyzed separately.

\section{Analytical methods}

The $\mathrm{HCO}_{3}{ }^{-}$concentrations were determined by acidic titration with $0.02 \mathrm{M} \mathrm{H}_{2} \mathrm{SO}_{4}$ within $48 \mathrm{~h}$ after sampling on unfiltered sample aliquots. For the analyses of major cations and anions, trace metals and organic carbon, the water samples were filtered in the laboratory using mixed cellulose ester membranes of $47-\mathrm{mm}$ diameter and a pore size of $0.22 \mu \mathrm{m}$ (Millipore GWSP) and a Nalgene polysulfone filtering unit with an electric vacuum pump. Each filter was rinsed with $150 \mathrm{ml}$ of ultra-pure water prior to filtering, and filtered samples were acidified to $\mathrm{pH} \mathrm{1-2} \mathrm{with} \mathrm{sub-}$ boiled distilled $\mathrm{HNO}_{3}$. The $0.22-\mu \mathrm{m}$-filtered fraction is hereafter called "dissolved fraction"; however, it has to be kept in mind that this fraction does not only contain really dissolved ions $(<5 \mathrm{~nm})$, but also poorly soluble elements sorbed on nanoparticles and colloids (NPCs) with a hydrodynamic diameter $<0.22 \mu \mathrm{m}$ (Atteia et al. 1998; Vesper and White 2003a; Gaillardet et al. 2005; Göppert and Goldscheider 2008).

In addition to the $<0.22-\mu \mathrm{m}$ dissolved fraction, also the $>0.22 \mu \mathrm{m}$ SPM fraction of a selected series of samples was analyzed by complete digestion of the filter membranes in a clean-lab. The filters were dried after filtering at $40{ }^{\circ} \mathrm{C}$ and the SPM weight was determined by subtracting the weight of the empty filter prior to filtering. For the chemical analyses of the filters, the same digestion procedure was used as for the rock and soil samples. The absolute SPM elemental concentrations were calculated by multiplying the analyzed concentrations with the $30 \mathrm{ml}$ of solution volume and normalized to the particle weight contained in the filter half. To compare the elemental concentrations of the SPM fraction with those of the dissolved fraction, SPM/dissolved load partition coefficients (Kd values) were calculated by simple division for those elements where data were available for both fractions. Filter blanks were determined by digestion of three new filters of the same batch. The average elemental concentrations of these blanks were compared with the average values obtained for the 21 SPM analyses. The results showed that the filter membranes contained astonishingly high concentrations of trace elements and that the blank contributions represented more than $10 \%$ of the analyzed SPM loads for the following elements: $\mathrm{Ba}, \mathrm{Cd}, \mathrm{Co}, \mathrm{Cr}, \mathrm{Eu}, \mathrm{La}, \mathrm{Mn}, \mathrm{Mo}$, $\mathrm{Na}, \mathrm{Ni}, \mathrm{Pb}, \mathrm{S}, \mathrm{Sc}, \mathrm{Sn}, \mathrm{Sr}, \mathrm{U}$. These elements were therefore omitted, and the SPM data presented here contain only elements with blank contributions $<10 \%$. No blank corrections were applied for these elements. The high filter blanks were probably also responsible for anomalously high La and Eu concentrations in the $<0.22-\mu \mathrm{m}$ filtered samples. Therefore also no $\mathrm{La}$ and $\mathrm{Eu}$ data are presented for the $<0.22-\mu \mathrm{m}$ dissolved fractions, which required the useage of a specific formula to calculate the Cerium (Ce) anomalies (see section 'Presentation and interpretation of REE data').

Rock samples were crushed and milled in an agate mill. About $20 \mathrm{mg}$ aliquots of sample powder were dissolved in Savillex Teflon vials using sub-boiled distilled $\mathrm{HNO}_{3} 65 \%$ and $\mathrm{HF} 40 \%$ of supra pure quality (Merck), evaporated, and finally redissolved in $30 \mathrm{ml}$ of $0.5 \mathrm{M} \mathrm{HNO}_{3}$ for ICP analysis. Soil samples were previously sieved (2-mm mesh size), followed by the same digestion and analytical procedure as for the rock samples. The stalactites and seep deposits were cleaned with ultrapure water (Millipore Milli-Q), dried at $40{ }^{\circ} \mathrm{C}$ and crushed and milled in an agate mill. About $40 \mathrm{mg}$ of sample powder were dissolved during $24 \mathrm{~h}$ in Savillex Teflon vials with $10 \mathrm{ml}$ of $2 \mathrm{M}$ subboiled distilled $\mathrm{HNO}_{3}$. After dissolution the samples were centrifuged to separate insoluble particulates and the supernatant was diluted to $40 \mathrm{ml}$ of $0.5 \mathrm{M} \mathrm{HNO}_{3}$ for ICP analysis.

The soil and bedrock samples were leached with ultrapure water (Millipore Milli-Q) in order to simulate water/soil interaction under controlled conditions according to the French standardized procedure AFNOR X31-210. Two 
grams of sample were continuously agitated during $24 \mathrm{~h}$ in $50 \mathrm{~mL}$ centrifuge tubes containing $20 \mathrm{~mL}$ of ultrapure water. Afterwards the samples were centrifuged, and the supernatant was filtered, acidified and analyzed according to the same procedure as the spring water samples.

All chemical analyzes were done at the Chrono-Environnement institute (CNRS-University of Burgundy FrancheComté, Besançon, France). Major cations and trace elements were determined by ICP-AES (Thermo iCap 6500) and ICP-MS (Thermo Xseries 2), respectively, with a precision of $< \pm 10 \%$. Anion analyses of $\mathrm{SO}_{4}{ }^{2-}, \mathrm{NO}_{3}{ }^{-}$, and $\mathrm{Cl}^{-}$were realized by HPLC (Dionex DX 100) with detection limits of $0.1,0.05$ and $0.1 \mathrm{mg} / \mathrm{L}$, respectively. Dissolved organic carbon (DOC) was analyzed by catalytic combustion using an Elementar vario TOC cube. All ionic balances were better than $5 \%$, validating sampling and chemical analyses. The $\mathrm{CaCO}_{3}$ and organic carbon content of rock and soil samples were determined by calcimetry and an Elementar Vario MAX carbon analyzer, respectively. The physicochemical parameters and the major element and DOC concentrations of the $<0.22-\mu \mathrm{m}$ dissolved fractions are given in Table 1. All other chemical data are available as electronic supplementary material (ESM).

\section{Presentation and interpretation of REE data}

This section presents a short introduction to REE geochemistry. More detailed information on the origin and the environmental behavior of the REE can be found in the recent outline of Brioschi et al. (2013). The REE include the lanthanide group and yttrium. REE data are typically presented as distribution patterns with the individual REE, listed in the order of their atomic number, as categories on the $\mathrm{x}$-axis and with the corresponding concentrations as normalized logarithmic values on the y-axis. For surface environments the REE are usually normalized to the PAAS standard (Post Archean Australian Shales; Taylor and McLennan 1985), which is the most commonly used standard for average upper continental crust.

The REE series can be separated into three sub-groups according to their atomic weight: the light REE (LREE, La$\mathrm{Sm}$ ), the medium REE (MREE, Eu-Td) and the heavy REE (HREE, Dy-Lu). Specific peaks of REE distribution patterns are called "anomalies". Commonly occurring anomalies are $\in$ Cerium $(\mathrm{Ce})$ anomalies and Europium (Eu) anomalies, which are quantified by $\mathrm{Ce} / \mathrm{Ce} *$ and $\mathrm{Eu} / \mathrm{Eu} *$ ratios, respectively. These ratios basically compare normalized $\mathrm{Ce}$ and $\mathrm{Eu}$ sample concentrations with $\mathrm{Ce}^{*}$ and $\mathrm{Eu}^{*}$ values, which are interpolated values based on the measured concentrations of the neighbor elements of $\mathrm{Ce}$ and $\mathrm{Eu}$, respectively. Here only $\mathrm{Ce} / \mathrm{Ce}$ * values are used, which are usually calculated by the following formula (McLennan 1989):

$$
\mathrm{Ce} / \mathrm{Ce}^{*}{ }_{\text {PAAS }}=\frac{3 \mathrm{Ce}_{\mathrm{PAAS}}}{2 \mathrm{La} \mathrm{PAAS}_{\mathrm{PAS}}+\mathrm{Nd}_{\mathrm{PAAS}}}
$$

with the subscript "PAAS" standing for PAAS-normalized values. However, in the present paper this formula could not be applied because of the high filter blanks for La (see section 'Analytical methods'). An alternative formula based on Nd and Pr concentrations was therefore used (Zhou et al. 2008, 2012):

$$
\mathrm{Ce} / \mathrm{Ce}^{*}{ }_{\mathrm{PAAS}}=\frac{\mathrm{Ce}_{\mathrm{PAAS}}}{\left[\mathrm{Pr}_{\mathrm{PAAS}}^{2} / \mathrm{Nd}_{\mathrm{PAAS}}\right]}
$$

Anomalies with $\mathrm{Ce} / \mathrm{Ce}$ * ratios $>1$ appear as positive peaks in a REE pattern and are therefore referred to as "positive anomalies", whereas $\mathrm{Ce} / \mathrm{Ce}^{*}<1$ yield negative peaks called "negative anomalies". Cerium anomalies are related to the specific redox behavior of $\mathrm{Ce}$ in surface environments. Under oxidizing conditions $\mathrm{Ce}$ does not occur in trivalent form as do the other REE, but as insoluble $\mathrm{Ce}^{4+}$, fixed in most cases in Fe-Mn oxyhydroxides (Braun et al. 1990; Koeppenkastrop and De Carlo 1992; Laveuf et al. 2012; Brioschi et al. 2013), which leads, during soil/water interaction, to preferential retention of $\mathrm{Ce}$ in $\mathrm{Fe}-\mathrm{Mn}$ oxyhydroxide bearing soil particles and to depletion of $\mathrm{Ce}$ in the corresponding soil water fraction. As a result, the waters will have negative Ce anomalies, whereas those of the corresponding Fe-Mn oxyhydroxide particles will be positive, a contrast that will become more and more accentuated with ongoing water/soil interaction (Feng 2010; Laveuf et al. 2012). Negative Ce anomalies of surface and groundwaters, becoming less negative during storms, basically reflect progressive admixture of NPCs and SPM with lacking or positive Ce anomalies. Such diminishing negative Ce anomalies in water samples are, in most cases, coupled with increasing total REE concentrations (Steinmann and Stille 2008; Filippini et al. 2018).

The total REE concentration of a sample is often described in the literature by the sum of the individual REE 
( $\Sigma \mathrm{REE}$ ); however, $\Sigma \mathrm{REE}$ values are strongly influenced by the anomalous behavior of specific REE such as Ce or $\mathrm{Eu}$. Therefore, concentrations of neodymium $(\mathrm{Nd})$ will be used here rather than $\Sigma$ REE values, because they give a more reliable measure for the overall REE content of a sample.

\section{Results}

\section{Physico-chemical parameters and major elements}

The evolution of rainfall, discharge, physico-chemical parameters, major elements and DOC concentrations of $0.22-\mu \mathrm{m}$ filtered samples during the storm event are shown in Fig. 2. The evolution was characterized by a positive peak for electrical conductivity (EC) occurring at the beginning of discharge increase. This EC peak was synchronous with positive peaks for $\mathrm{K}^{+}, \mathrm{Si}$ and $\mathrm{SO}_{4}{ }^{2-}$, and decreasing $\mathrm{Mg}^{2+}$ and $\mathrm{HCO}_{3}{ }^{-}$concentrations and $\mathrm{Mg}^{2+} / \mathrm{Ca}^{2+}$ ratios. This first series of synchronous events is marked in Fig. 2 by a grayed field named storm stage 1 hereafter. Storm stage 1 was followed by storm stage 2, highlighted by a hatched field in Fig. 2, with positive peaks for turbidity, suspended matter, dissolved organic carbon (DOC), and $\mathrm{NO}_{3}{ }^{-}$.

This succession of two distinct storm stages is also shown by the principal component analysis (PCA) of the individuals (Fig. 3). The primary axis, explaining $51 \%$ of the variance, is related to turbidity, DOC and $\mathrm{NO}_{3}{ }^{-}=$and distinguishes event infiltration water with high $\mathrm{DOC}$ and $\mathrm{NO}_{3}{ }^{-}$of storm stage 2 from pre-event water with high $\mathrm{Mg}^{2+} / \mathrm{Ca}^{2+}$ ratios and $\mathrm{HCO}_{3}{ }^{-}$concentrations (negative correlation). The secondary axis, explaining $34 \%$ of the variance, is related to $\mathrm{K}^{+}, \mathrm{Si}$, and $\mathrm{SO}_{4}{ }^{2-}$ from storm stage 1 . The individual samples describe a clockwise rotation in the PCA diagram, evolving first during storm stage 1 towards positive values on the secondary axis, followed during storm stage 2 by a shift towards positive values on the primary axis, and finally approaching the point of origin during recession.

Fig. 3

PCA diagram of the individual components for $0.22-\mu \mathrm{m}$ filtered samples

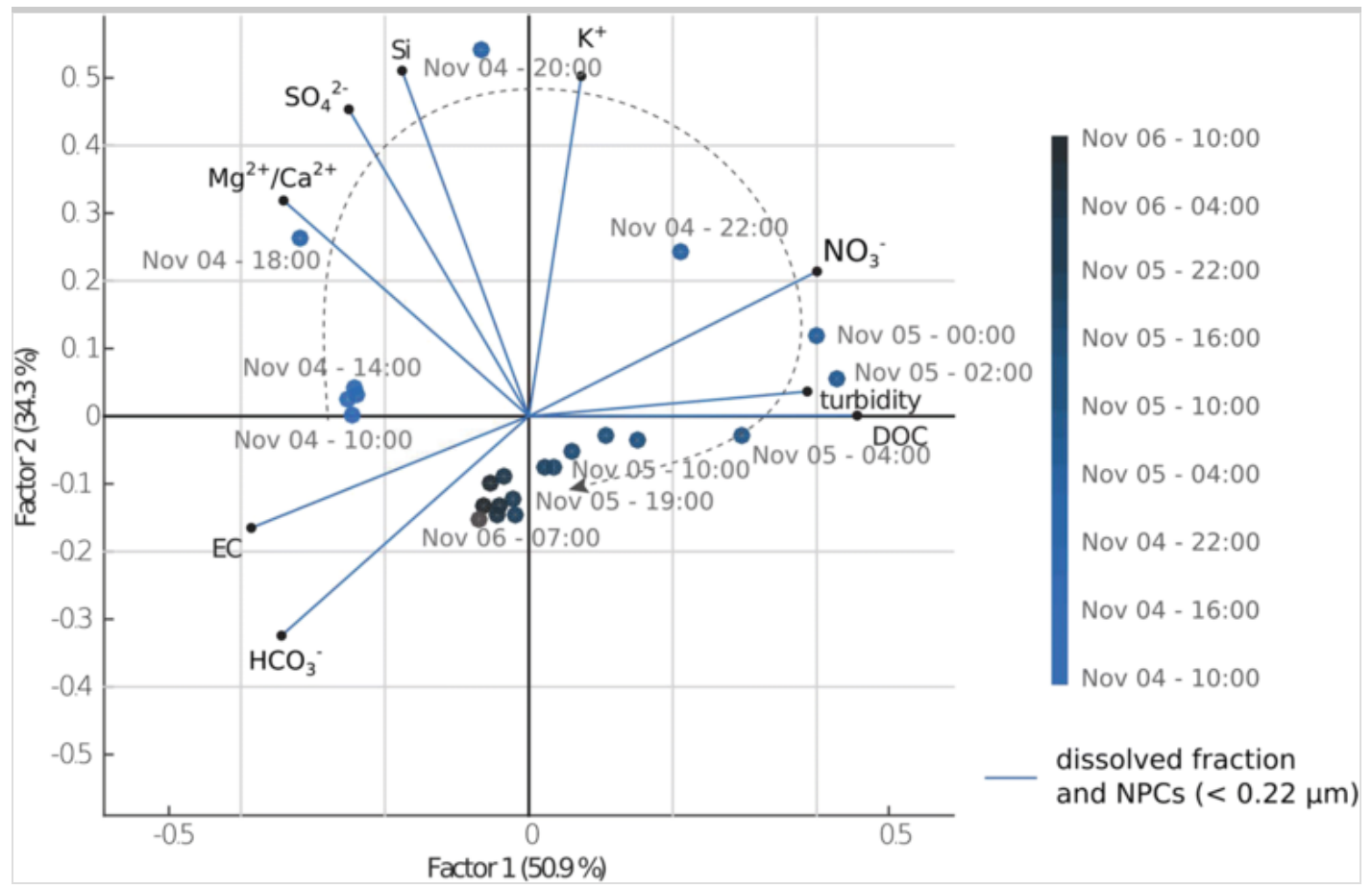

\section{Trace elements}

Figure 4 presents a synthesis of the temporal evolution of the dissolved and particulate trace element concentrations and compares them with the hydrological data presented in Fig. 2. Each line of the figure corresponds to a colorcoded normalized parameter varying between 0 (minimum, dark blue) and 1 (maximum, bright yellow). The representation in Fig. 4 allows to subdivide the storm into four stages according to the yellow peak zones: ( $4 \mathrm{i})$ preevent conditions with high EC, $\mathrm{Mg}^{2+}, \mathrm{Sr}, \mathrm{HCO}_{3}{ }^{-}$and $\mathrm{Mg}^{2+} / \mathrm{Ca}^{2+}$, (zii) and (3iii) storm stages 1 and 2 as defined in section 'Physio-chemical parameters and major elements', and (4iv) a lingering recession. Figure 4 shows that the 
peak concentrations of some elements of the dissolved and the SPM fractions were related to storm stage 1, whereas others achieved highest concentrations during stage 2. For the dissolved fraction only $\mathrm{Rb}$ and Si reached their peaks during stage 1 together with $\mathrm{K}^{+}$and $\mathrm{Cl}^{-}$, whereas all other trace elements (Al, Mn, Co, Nd) showed highest concentrations during stage 2 . For the SPM fraction, $\mathrm{Rb}, \mathrm{Co}, \mathrm{Pb}$, and $\mathrm{Nd}$ were related to stage 1 , and $\mathrm{K}^{+}, \mathrm{Al}, \mathrm{Fe}$, and $\mathrm{Mn}$ to stage 2. Cobalt, $\mathrm{Rb}$ and $\mathrm{Nd}$ had highest $\mathrm{Kd}$-values during storm stage 1 , whereas $\mathrm{K}^{+}, \mathrm{Al}$, and Mn achieved maximum values during stage 2 . No Kd-values could be calculated for $\mathrm{Fe}$, because its concentrations were beneath detection limits in the $<0.22-\mu \mathrm{m}$ fraction.

\section{Fig. 4}

Synthesis of the evolution of rainfall, discharge (Q), temperature, turbidity, electrical conductivity (EC), and the chemical composition of the dissolved and the SPM fraction during the storm event, expressed as normalized values (from 0 in dark blue color to 1 in bright yellow). The lowermost block shows the SPM/dissolved load partition coefficients $\mathrm{Kd}$ for elements analyzed in both fractions

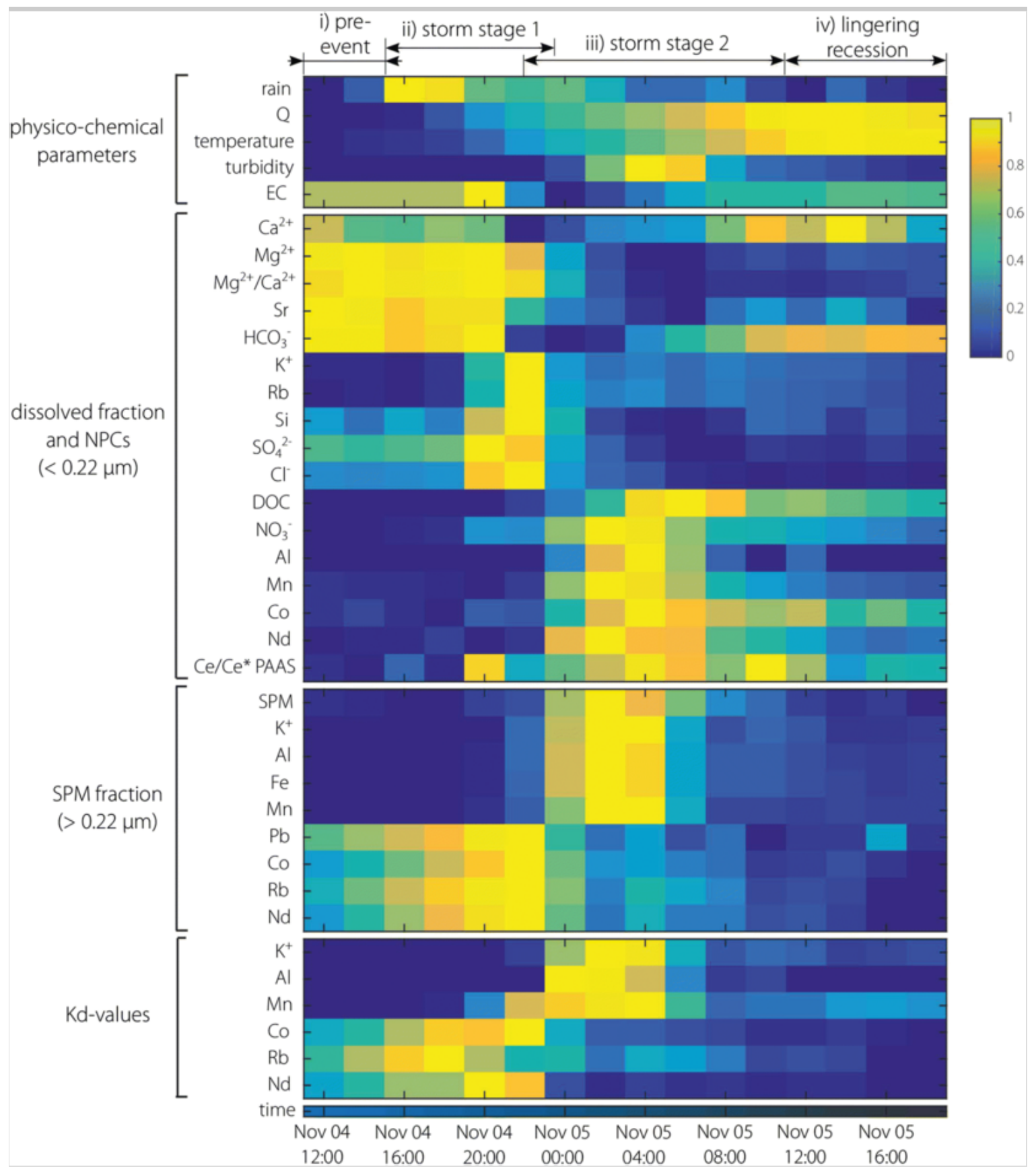

\section{Rare earth elements (REE)}

The REE of the dissolved fraction achieved highest concentrations during storm stage 2, which was also characterized by elevated DOC and $\mathrm{NO}_{3}{ }^{-}$concentrations (Fig. 4). The PAAS-normalized REE patterns of the 
dissolved fractions had negative Ce anomalies (Fig. 5) with $\mathrm{Ce} / \mathrm{Ce}^{*}$ around 0.1 at the beginning of the storm (Fig. 6). Towards the storm peak the anomalies became less negative, reaching values above 0.5 . This evolution was thus identical to Nd concentrations, showing that the most REE of the dissolved fraction arrived arriving at the karst spring during storm stage 2 and that they were derived from a REE source with less negative Ce anomalies than preevent water (Fig. 6). Fromis follows that of the dissolved fration arived 2.

Fig. 5

Upper Continental Crust (PAAS) - normalized REE distribution patterns of spring water, soil and rock samples. The soil and rock leachates are laboratory batch leachates with distilled water. All soil and rock data are average values from three subsamples; standard deviations are not shown to ensure the readability of the figure. No La and Eu data are given for spring water samples because of high filter blanks (section 'Analytical methods')

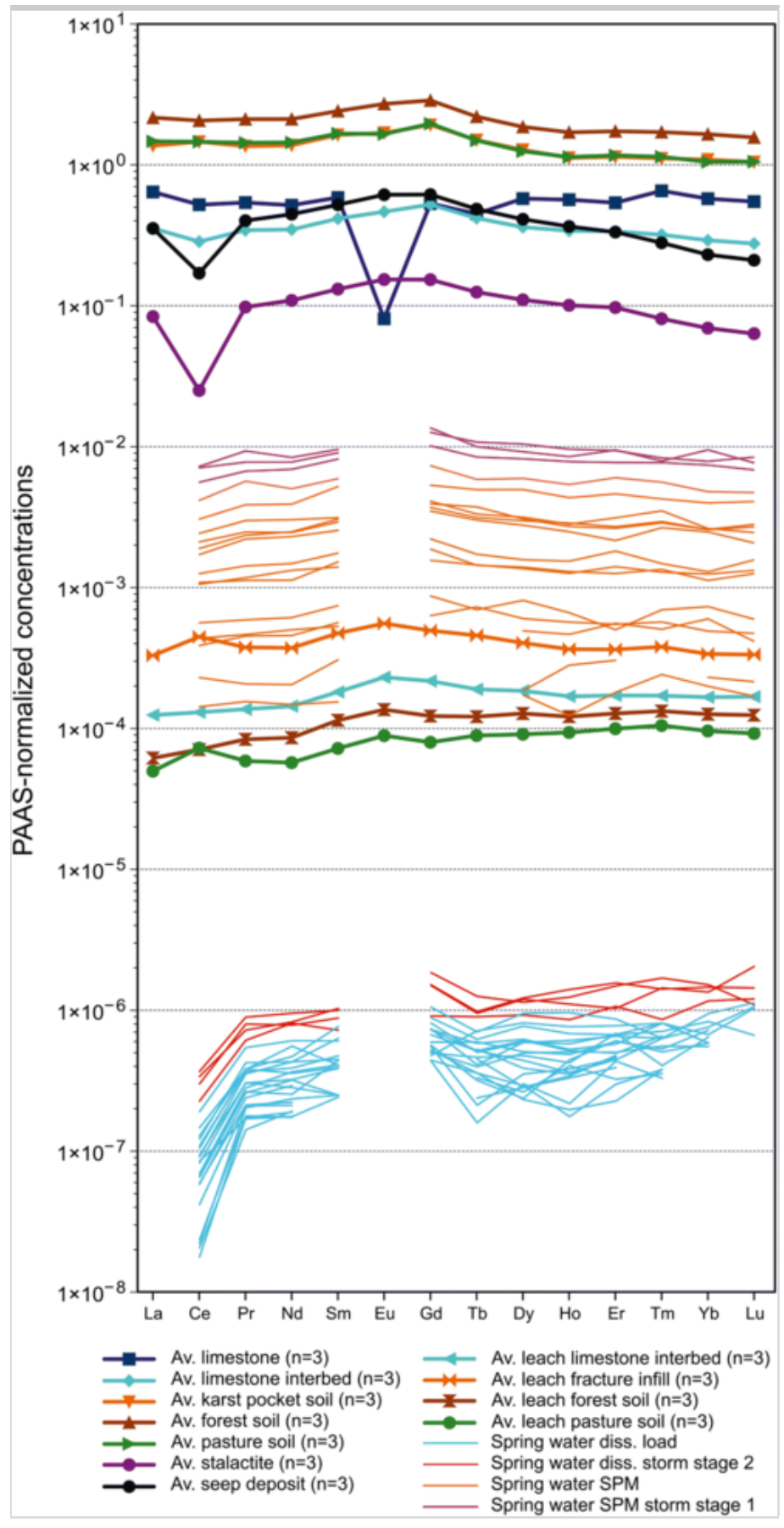

Fig. 6

Evolution of $\mathrm{Nd}$ concentrations and $\mathrm{Ce}$ anomalies of $<0.22-\mu \mathrm{m}$-filtered spring water fractions, and of $\mathrm{Nd}$ concentrations of the $>0.22-\mu \mathrm{m}$ SPM fractions during the flood event 


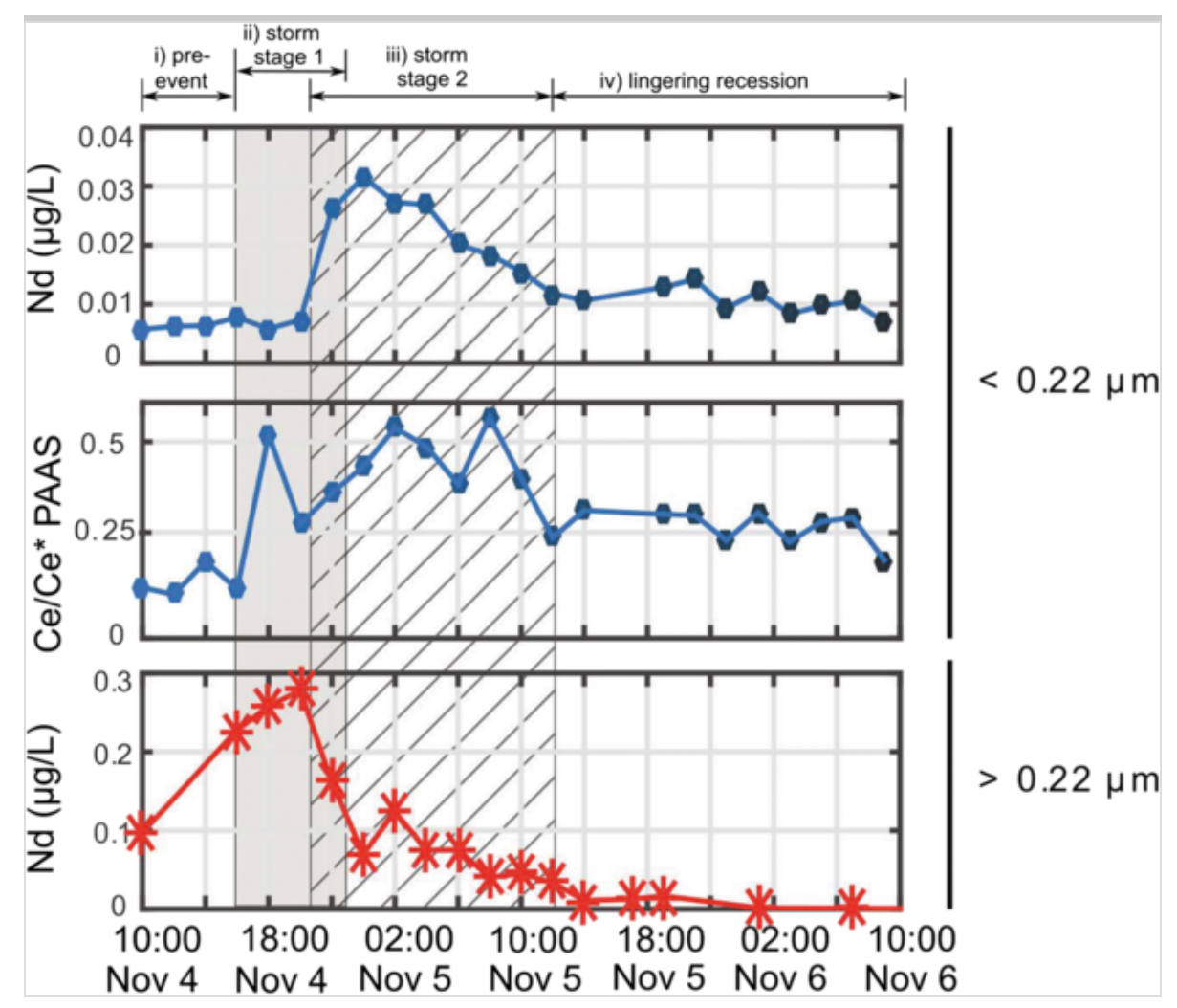

The REE concentrations of the SPM fraction were about 10-fold higher than for the dissolved fraction (Fig. 6). The PAAS-normalized REE patterns were almost flat and had, in contrast to the dissolved fraction, no negative Ce anomalies (Fig. 5). This flat shape of the REE patterns did not evolve during the storm. In contrast, the $\mathrm{Nd}$ concentrations of the SPM fraction in Fig. 6 showed, the same as for the dissolved fraction, a clear peak, which was however unlike that for the dissolved fraction during storm stage 2. $\mathrm{P}$ during storm stage 1, they appeared simultaneously with the SPM-related peaks of $\mathrm{Rb}, \mathrm{Co}$, and $\mathrm{Pb}$ (Fig. 4).

The averaged REE patterns of the bulk rock and soil samples are presented in Fig. 5, together with the corresponding water-leachates. The patterns of the bulk samples were flat, except for the limestone, which had a negative Eu anomaly. The patterns of the water-leachates were the same for the bulk samples, almost flat without specific anomalies. In contrast, the REE patterns of the stalactites and the seep deposits showed strong negative Ce anomalies and an enrichment of the medium REE. The REE patterns of the stalactites and the seep deposits were thus clearly different from those of the soils, the limestone interbeds (bulk and leachates), and the SPM samples.

\section{Discussion}

\section{Contributions of pre-event and event water}

The storm event was characterized by two stages with contrasted hydrochemical signatures. The first stage with high values for $\mathrm{EC}, \mathrm{K}^{+}, \mathrm{Si}$, and $\mathrm{SO}_{4}{ }^{2-}$ occurred at the beginning of discharge increase, the same time $\mathrm{Mg}^{2+} / \mathrm{Ca}^{2+}$ ratios and $\mathrm{HCO}_{3}{ }^{-}$concentrations started to decrease (Fig. 3). High $\mathrm{Mg}^{2+}$ and $\mathrm{HCO}_{3}{ }^{-}$concentrations are, like elevated $\mathrm{Mg}^{2+} / \mathrm{Ca}^{2+}$ ratios, good indicators for long residence-time karst water (Batiot et al. 2003; Celle-Jeanton et al. 2003; Binet et al. 2006), suggesting that the first peak corresponded to pre-event water purged at the beginning of the storm by piston-effect. This pre-event water was enriched in well soluble ions such as $\mathrm{K}^{+}, \mathrm{Rb}, \mathrm{Sr}, \mathrm{Si}$, and $\mathrm{SO}_{4}{ }^{2-}$. $\mathrm{Storm}^{-}$ stage 2 occurred during maximum discharge and was characterized by high SPM load and turbidity, and high DOC and $\mathrm{NO}_{3}{ }^{-}$concentrations, which is typical for event water from rapid surface infiltration (Mudarra et al. 2014).

Storm stages 1 and 2 thus reflect the classical scheme for storm events in karst aquifers with pre-event water expelled by piston-effect at the beginning of the storm, followed by event water from surface infiltration (White 2002). In the present case, pre-event water represented only $5 \%$ of the total storm flow volume, showing that pistontype flow was a minor process compared to recharge from surface. Even if pre-event/event water contributions may vary with time according to hydrological conditions (Charlier et al. 2012), this contribution of pre-event water is below values in the literature, where typical values from 20 to 100\% are given (Ryan and Meiman 1996; Lee and 
Krothe 2003; Aquilina et al. 2006; Charlier et al. 2012), which can be explained by the local hydrogeological context of the Dahon aquifer with a clay layer just beneath the spring. This clay layer may have limited the development of a deep saturated zone, thus leading to a reduced storage volume compared to the recharge area. Alternatively, the clay layer may not have been completely impervious and pre-event water was lost towards deeper aquifers.

\section{Origin of SPM and NPC hosted trace elements}

Storm stages 1 and 2 had distinct chemical SPM and NPC signatures. The SPM of storm stage 1 were rich in $\mathrm{Pb}, \mathrm{Co}$, $\mathrm{Rb}$ and $\mathrm{Nd}$ (Fig. 4) and arrived together with pre-event water, suggesting that these particulates were of autochthonous origin and mobilized by piston-flow. Note that this peak appeared only in the chemical data and was not visible in the SPM load and turbidity data (Fig. 4); however, the contribution of pre-event water to total storm flow was, as shown in section 'Contributions of pre-event and event water', below literature values. It can therefore be expected that the relative contribution of SPM-hosted trace elements mobilized by pre-event water may be higher in karst aquifers with deeper saturated zones.

The SPM associated with storm stage 2 had high concentrations of $\mathrm{K}^{+}, \mathrm{Al}, \mathrm{Fe}$, and Mn. Particulate $\mathrm{K}^{+}$and $\mathrm{Al}$ in soils are usually derived from clays, whereas $\mathrm{Fe}$ and $\mathrm{Mn}$ are derived from oxyhydroxide particles. Both particles are typically associated with the clay-humus complex (Steinmann and Stille 1997; Brioschi et al. 2013). Therefore the concentration peaks of $\mathrm{K}^{+}, \mathrm{Al}, \mathrm{Fe}$, and $\mathrm{Mn}$ of the SPM of storm stage 2 can be related to the arrival of allochthonous clay and Fe-Mn oxyhydroxide particles washed out from the soils of the infiltration zone, together with DOC and $\mathrm{NO}_{3}{ }^{-}$, leading to high SPM loads and turbidity values. This relation between SPM and soil particles is corroborated by the binary plot of Fig. 7, which shows that the increasing Fe and Al concentrations of SPM were correlated and approached progressively typical values of local soil during storm stage 2 .

\section{Fig. 7}

$\mathrm{Fe}$ and $\mathrm{Al}$ concentrations of the $>0.22 \mu \mathrm{m}$ SPM fractions compared with local rock and soils. The SPM samples reached highest $\mathrm{Al}$ and $\mathrm{Fe}$ concentrations during storm stage 2, approaching values typical for soils and shale interbeds

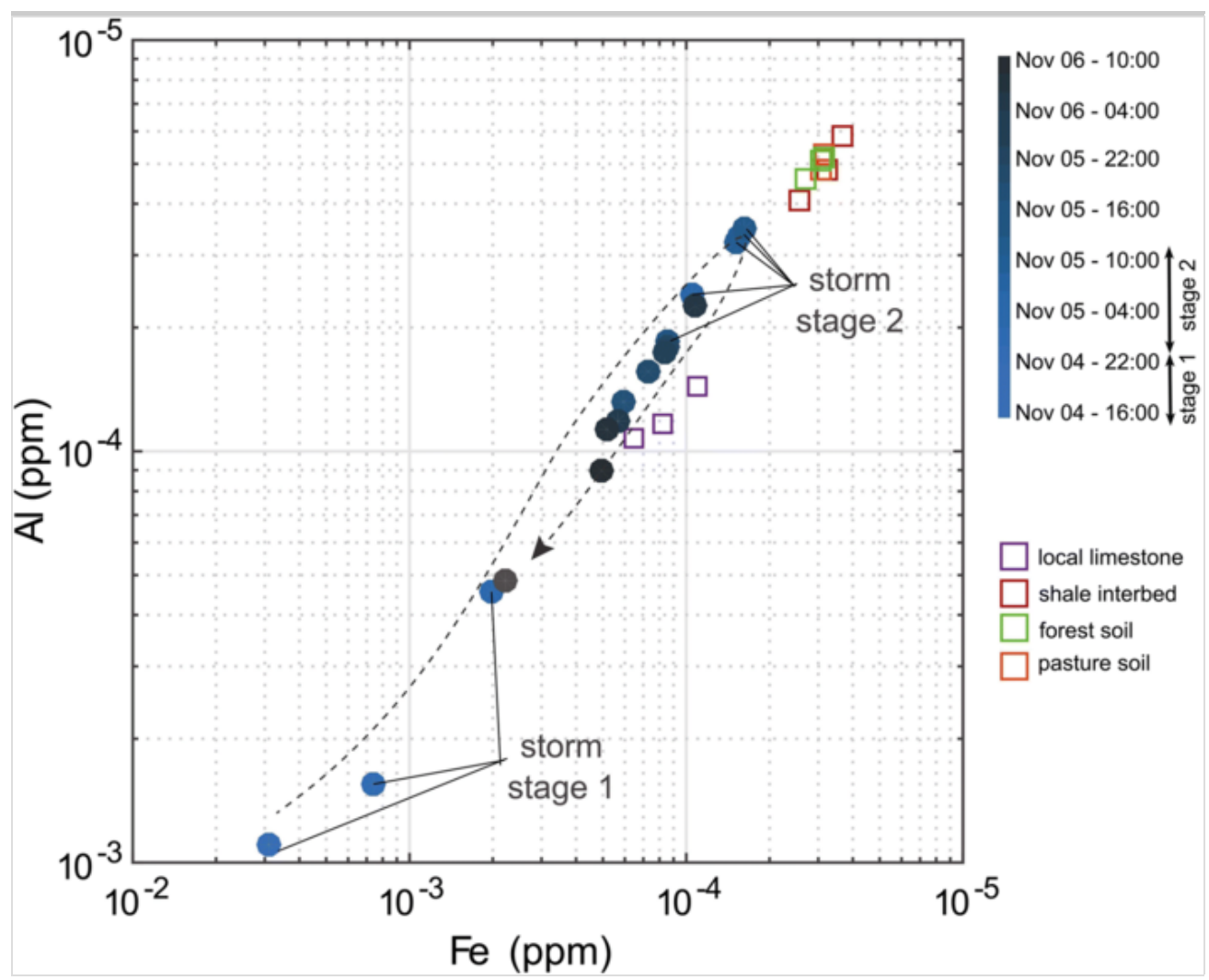

During storm stage 2 simultaneous peaks occurred for the SPM load and for dissolved Al, Mn, Ni, Co, and Nd (Fig. 4). The elements $\mathrm{Al}, \mathrm{Mn}, \mathrm{Ni}, \mathrm{Co}$, and $\mathrm{Nd}$ are poorly soluble trace metals and their presence in the dissolved fraction at basic $\mathrm{pH}$ is indicative for the presence of nanoparticles and colloids (NPCs; Atteia 1992; Vesper and White 2003a; Gaillardet et al. 2005; Andersson et al. 2006; Dahlqvist et al. 2007). The synchronous arrival of trace metal-bearing NPCs and SPM during storm stage 2 suggests that the NPCs represented essentially the fine fraction of SPM and that 
both were concomitantly washed out from the soils. This hypothesis is ascertained by the evolution of the Ce anomalies of the NPC load. The $\mathrm{Ce} / \mathrm{Ce}^{*}$ values were correlated with $\mathrm{Nd}$ concentrations, showing that the REE of the dissolved fraction were controlled by binary mixing between pre-event water with low $\mathrm{Nd}$ concentrations and strong negative $\mathrm{Ce}$ anomalies $\left(\mathrm{Ce} / \mathrm{Ce}^{*} \sim 0.1\right.$ ), and a Nd-rich end-member with $\mathrm{Ce} / \mathrm{Ce} \mathrm{e}^{*}>0.5$ (Figs. 5 and 6 ). This second end-member was most probably soil. Hartland et al. (2012) showed, similarly for dripwaters in karst caves, that soilderived NPCs and SPM appeared simultaneously in the cave during storm events, and that the soil-derived NPCs were mainly composed of Fe-bearing humic-like organic matter, which is a well-known vector for trace element transport in aquatic systems (Dahlqvist et al. 2007; Pokrovsky et al. 2016).

In summary, the data set documents the existence of 2 distinct SPM peaks. The first peak arriving during storm stage 1 was composed of autochthonous particulates, whereas the second peak occurred during storm stage 2 and contained allochthonous, soil-derived SPM. Peak 2 was, in contrast to peak 1, accompanied by trace element-bearing NPCs, which can be considered as the fine fraction of SPM. The first SPM peak was not visible in the turbidity record, but only in the chemical composition of the SPM fraction. This relative scarcity of autochthonous particles was most probably due-only to an only small head increase after recharge and/or to a limited storage capacity for particles inside the conduit network.

Based on turbidity data, a similar succession of autochthonous and allochthonous SPM peaks was described in the literature for karst systems with allogenic recharge via swallow holes, favoring SPM transport from the surface (Massei et al. 2003; Pronk et al. 2006, 2007, 2009). The present data thus document an analogous behavior for a karst system recharged only by diffuse infiltration through soil and epikarst. The current conceptual model, which attributes the presence of allochthonous SPM in underground karst networks solely to allogenic recharge through swallow holes, must therefore be revised. Accordingly, significant quantities of allochthonous soil particles may also be transported into karst aquifers via diffuse infiltration, most probably through small fractures in the epikarst. This aspect should be considered and evaluated in more detail in future works.

\section{Origin of the chemical load of SPM peak 1}

The chemical load of the autochthonous SPM peak 1 could basically be derived from reworking of allochthonous particulates deposited by the cave stream during previous storms, or from mobilization of authigenic precipitates such as Fe-Mn oxyhydroxides or calcite crusts from speleothems formed by groundwater seepage through the microfractured rock matrix. Fe-Mn oxyhydroxides would in both cases be the main carrier phase for trace elements (Vesper and White 2003b; White et al. 2009; Frierdich et al. 2011; Frierdich and Catalano 2012). In the present case, the REE patterns of all SPM samples were flat and very different from the stalactites and the seep deposits, which showed negative Ce anomalies and an enrichment of the medium REE (Fig. 5). Such REE patterns are typical for secondary precipitates (see section 'Presentation and interpretation of REE data') and resemble those described by Zhou et al. $(2012,2008)$ for the Holocene part of a large stalactite from Central China, and by Bourdin et al. (2011) for a stalagmite from SE France. The flat REE patterns of the SPM samples thus clearly exclude a significant contribution of authigenic precipitates such as Fe-Mn oxyhydroxides and speleothems, and demonstrate that the trace metal content of SPM peak 1 was derived from reworked allochthonous particulates.

\section{Trace element partitioning between "dissolved" and particulate fractions}

Figure 8 shows the partitioning of the trace metals between the dissolved and the SPM fractions during the storm event, together with the typically soluble major cations $\left(\mathrm{Na}^{+}, \mathrm{K}^{+}, \mathrm{Ca}^{2+}, \mathrm{Mg}^{2+}\right)$ for comparison. The diagram furthermore details the proportions of mass transfer related to storm stages 1 and 2.

\section{Fig. 8}

Partitioning of elemental transfers between the $<0.22-\mu \mathrm{m}$ dissolved fraction and NCPs (in blue) and the $>0.22-\mu \mathrm{m}$ SPM fraction (in red). The values are based on total fluxes integrated over the entire storm event. The portions of mass transfer related to storm stages 1 and 2 are superposed as patterns 


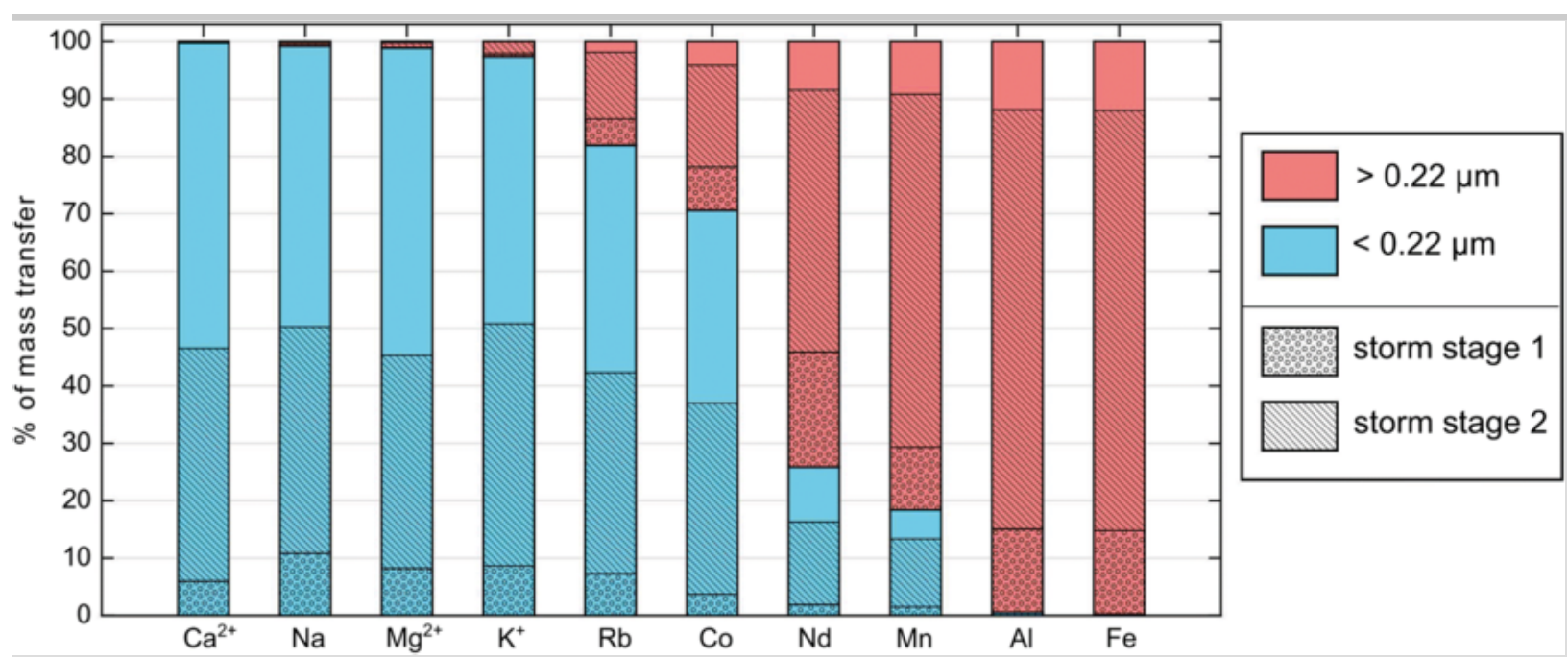

The major cations were indeed almost entirely transported as dissolved ions. They were continuously present during the entire storm event, with storm stages 1 and 2 representing less than $50 \%$ of the total fluxes of these elements. Only a few percent of $\mathrm{K}^{+}$and some $\mathrm{Mg}^{2+}$ were related to the SPM fraction of storm stage 2. Aluminum and iron showed, with respect to the major cations, a completely opposite behavior. They were, mainly during storm stage 2 , exclusively transported by the SPM fraction, demonstrating that the transport of these elements was entirely controlled by soil particles. The Kd values of $\mathrm{Al}$ were therefore highest during storm stage 2 (Fig. 4).

The trace elements $\mathrm{Rb}, \mathrm{Co}, \mathrm{Nd}$, and Mn showed an intermediate behavior. The SPM fraction was most important for $\mathrm{Mn}$, followed by $\mathrm{Nd}, \mathrm{Co}$, and $\mathrm{Rb}$. The $\mathrm{Kd}$-values of $\mathrm{Mn}$ reached highest values during storm stage 2, suggesting that $\mathrm{Mn}$ was like $\mathrm{Fe}$ and $\mathrm{Al}$, strongly controlled by soil particles. In contrast, the $\mathrm{Kd}$ values of $\mathrm{Rb}$, Co and Nd were highest during storm stage 1, showing that they were primarily related to autochthonous particles. However, Fig. 8 also shows, that considerable amounts of $\mathrm{Rb}, \mathrm{Co}, \mathrm{Nd}$, and $\mathrm{Mn}$ were related to the $<0.22-\mu \mathrm{m}$ fraction, which is interpreted, as discussed in section 'Origin of SPM and NPC hosted trace elements', by the arrival of soil-derived NPCs during storm stage 2 .

\section{Conclusions}

The aim of the present paper was to quantify chemical fluxes over time related to dissolved and suspended matter during a storm event in a karst aquifer, using various natural tracers. The combined utilization of major, trace, and rare earth elements (REE) allowed for the identification of the origin of the suspended particulate matter (SPM) during two subsequent storm stages. The SPM peak of storm stage 1, corresponding to autochthonous sediments mobilized at the beginning of the storm, contributed to up to $15 \%$ of the total mass balance for some trace metals such as Al, Fe, and REE, in spite of the fact that the SPM weight and the turbidity related to this fraction was negligible. In contrast, SPM peak 2 appeared as a clear peak in the SPM weight and turbidity record. SPM peak 2 was associated with event infiltrated water and its chemical composition was typical for soil particles. However, many trace elements of storm stage 2 were not related to SPM, but to the $<0.22-\mu \mathrm{m}$ dissolved fraction. It is suggested that these trace elements were not really dissolved, but sorbed on nanoparticles and colloids (NPCs) which had passed the filter membranes. The cerium (Ce) anomalies of this NPC fraction approached values typical for local soil, showing that the NPC were mobilized in the soils together with the SPM.

The REE distribution patterns of SPM peak 1 were, like SPM peak 2, similar to local soil and marly limestone interbeds, but clearly different from authigenic cave precipitates (stalactites, seep deposits). This demonstrates that the autochthonous SPM of peak 1 were simply reworked allochthonous particulates from previous storms. The REE distribution patterns, and in particular the Ce anomalies, thus allowed to identify the origin of the trace elements, and to exclude authigenic precipitates as a significant source for autochthonous SPM. The data document the transport of surface-derived trace metals by autochthonous and allochthonous SPM in a karst system recharged only by diffuse infiltration, i.e. without allogenic recharge, which is currently considered as the main route for groundwater contamination by surface materials. This aspect should be taken into consideration for future studies.

\section{Acknowledgements}


The authors wish to thank Bruno Régent for his indispensable collaboration during fieldwork. Christophe Loup, Nadia Crini, and Caroline Amiot are thanked for the laboratory analyses. We would also like to thank the municipality of the village of Epenoy for giving access to their drinking-water-supply station. The Jurassic Karst hydrogeological observatory is part of the INSU/CNRS national observatory for karstic aquifers, SNO KARST ( http://www.sokarst.org ). The present paper profited from fruitful discussions with various colleagues of this network. The constructive reviews of N. Goldscheider and an anonymous reviewer helped to improve an earlier version of the manuscript.

Funding information

This work was carried out with the financial support of the Regional Council of Burgundy Franche-Comte and the French Geological Survey BRGM, which is kindly acknowledged.

\section{Electronic supplementary material}

\section{ESM 1}

(PDF $88 \mathrm{~kb}$ )

\section{References}

Amraoui F, Razack M, Bouchaou L (2003) Turbidity dynamics in karstic systems: example of Ribaa and Bittit springs in the Middle Atlas (Morocco). Hydrol Sci J 48:971-984

Andersson K, Dahlqvist R, Turner D, Stolpe B, Larsson T, Ingri J, Andersson P (2006) Colloidal rare earth elements in a boreal river: changing sources and distributions during the spring flood. Geochim Cosmochim Acta 70:3261-3274. https://doi.org/10.1016/j.gca.2006.04.021

Andreo B, Goldscheider N, Vías JM, Neukum C, Sinreich M, Jiménez P, Brechenmacher J, Carrasco F, Hötzl H, Perles MJ, Zwahlen F (2006) Karst groundwater protection: first application of a pan-European approach to vulnerability, hazard and risk mapping in the sierra de Líbar (southern Spain). Sci Total Environ 357:54-73. https://doi.org/10.1016/j.scitotenv.2005.05.019

Aquilina L, Ladouche B, Dörfliger N (2006) Water storage and transfer in the epikarst of karstic systems during high flow periods. J Hydrol 327:472-485

Atteia O (1992) Rôle du sol dans le transfert des éléments traces en solution: application à l'étude de quelques écosystèmes d'altitude [Role of the soil in the transfer of trace elements in solution: application to the study of some high altitude ecosystems]. PhD Thesis, EPFL, Lausanne, Switzerland. https://infoscience.epfl.ch/record /31509. Accessed August 2018

Atteia O, Perret D, Adatte T, Kozel R, Rossi P (1998) Characterization of natural colloids from a river and spring in a karstic basin. Environ Geol 34:257-269. https://doi.org/10.1007/s002540050277

Batiot C, Emblanch C, Blavoux B (2003) Carbone organique total (COT) et magnésium $\left(\mathrm{Mg}^{2+}\right)$ : deux traceurs complémentaires du temps de séjour dans l'aquifère karstique [Total organic carbon (TOC) and magnesium $\left(\mathrm{Mg}^{2+}\right)$ : two complementary tracers of residence time in karstic systems]. C R Geosci 335:205-214. https://doi.org/10.1016/S1631-0713(03)00027-0

Binet S, Mudry J, Bertrand C, Guglielmi Y, Cova R (2006) Estimation of quantitative descriptors of northeastern Mediterranean karst behavior: multiparametric study and local validation of the Siou-Blanc Massif (Toulon, France). Hydrogeol J 14:1107-1121. https://doi.org/10.1007/s10040-006-0044-1

Bourdin C, Douville E, Genty D (2011) Alkaline-earth metal and rare-earth element incorporation control by ionic radius and growth rate on a stalagmite from the Chauvet cave, southeastern France. Chem Geol 290:1-11. https://doi.org/10.1016/j.chemgeo.2011.08.006 
Braun JJ, Pagel M, Muller JP, Bilong P, Michard A, Guillet B (1990) Cerium anomalies in lateritic profiles. Geochim Cosmochim Acta 54:781-795

Brioschi L, Steinmann M, Lucot E, Pierret MC, Stille P, Prunier J, Badot PM (2013) Transfer of rare earth elements (REE) from natural soil to plant systems: implications for the environmental availability of anthropogenic REE. Plant Soil 366:143-163. https://doi.org/10.1007/s11104-012-1407-0

Caetano Bicalho C, Batiot-Guilhe C, Seidel J, Van Exter S , Jourde H (2012) Geochemical evidence of water source characterization and hydrodynamic responses in a karst aquifer. J Hydrol 450-451:206-218

Celle-Jeanton H, Emblanch C, Mudry J, Charmoille A (2003) Contribution of time tracers $\left(\mathrm{Mg}^{2+}, \mathrm{TOC}^{2} \delta^{13} \mathrm{C}_{\mathrm{TDIC}}\right.$, $\mathrm{NO}_{3}{ }^{-}$) to understand the role of the unsaturated zone: a case study - karst aquifers in the Doubs Valley, eastern France. Geophys Res Lett 30:1322. https://doi.org/10.1029/2002GL016781

Charlier J-B, Bertrand C, Mudry J (2012) Conceptual hydrogeological model of flow and transport of dissolved organic carbon in a small Jura karst system. J Hydrol 460-461:52-64. https://doi.org/10.1016

/j.jhydrol.2012.06.043

Chen Z, Auler AS, Bakalowicz M, Drew D, Griger F, Hartmann J, Jiang G, Moosdorf N, Richts A, Stevanovic Z, Veni G, Goldscheider N (2017) The world karst aquifer mapping project: concept, mapping procedure and map of Europe. Hydrogeol J 25:771-785. https://doi.org/10.1007/s10040-016-1519-3

Cholet C (2017) Fonctionnement hydrogéologique et processus de transport dans les aquifères karstiques du Massif du Jura [Hydrogeological functioning and transport processes in the karst aquifers of the Jura Mountains]. PhD Thesis, University of Burgundy/Franche-Comté, Dijon, France. https://hal.archives-ouvertes.fr/tel-01617489 . Accessed August 2018

Cholet C, Charlier J-B, Moussa R, Steinmann M, Denimal S (2017) Assessing lateral flows and solute transport during floods in a conduit-flow-dominated karst system using the inverse problem for the advection-diffusion equation. Hydrol Earth Syst Sci 21:3635-3653. https://doi.org/10.5194/hess-21-3635-2017

Dahlqvist R, Andersson K, Ingri J, Larsson T, Stolpe B, Turner D (2007) Temporal variations of colloidal carrier phases and associated trace elements in a boreal river. Geochim Cosmochim Acta 71:5339-5354. https://doi.org /10.1016/j.gca.2007.09.016

Drew D, Hötzl H (1999) Karst hydrogeology and human activities: impacts, consequences and implications. Balkema, Rotterdam, The Netherlands

Dussart-Baptista L, Massei N, Dupont J-P, Jouenne T (2003) Transfer of bacteria-contaminated particles in a karst aquifer: evolution of contaminated materials from a sinkhole to a spring. J Hydrol 284:285-295. https://doi.org /10.1016/j.jhydrol.2003.08.007

Feng J-L (2010) Behaviour of rare earth elements and yttrium in ferromanganese concretions, gibbsite spots, and the surrounding terra rossa over dolomite during chemical weathering. Chem Geol 271:112-132. https://doi.org /10.1016/j.chemgeo.2010.01.003

Filippini M, Squarzoni G, De Waele J, Fiorucci A, Vigna B, Grillo B, Riva A, Rossetti S, Zini L, Casagrande G, Stumpp C, Gargini A (2018) Differentiated spring behavior under changing hydrological conditions in an alpine karst aquifer. J Hydrol 556:572-584. https://doi.org/10.1016/j.jhydrol.2017.11.040

Ford D, Williams PD (2007) Karst hydrogeology and geomorphology. Wiley, Chichester, UK

Fournier M, Motelay-Massei A, Massei N, Aubert M, Bakalowicz M, Dupont JP (2009) Investigation of transport processes inside karst aquifer by means of STATIS. Ground Water 47:391-400

Frederickson GC, Criss RE (1999) Isotope hydrology and residence times of the unimpounded Meramec River basin, Missouri. Chem Geol 157:303-317. https://doi.org/10.1016/S0009-2541(99)00008-X 
Frierdich AJ, Catalano JG (2012) Distribution and speciation of trace elements in iron and manganese oxide cave deposits. Geochim Cosmochim Acta 91:240-253

Frierdich AJ, Hasenmueller EA, Catalano JG (2011) Composition and structure of nanocrystalline Fe and Mn oxide cave deposits: implications for trace element mobility in karst systems. Chem Geol 284:82-96

Gaillardet J, Viers J, Dupré B (2005) Trace elements in river waters. In: Surface and ground water, weathering, and soils. Elsevier, Amsterdam, pp 225-272

Goldscheider N, Drew D (2007) Methods in karst hydrogeology. In: IAH International Contributions to Hydrogeology 26. CRC, Boca Raton, FL

Göppert N, Goldscheider N (2008) Solute and colloid transport in karst conduits under low- and high-flow conditions. Ground Water 46:61-68. https://doi.org/10.1111/j.1745-6584.2007.00373.x

Hartland A, Fairchild IJ, Lead JR, Borsato A, Baker A, Frisia S, Baalousha M (2012) From soil to cave: transport of trace metals by natural organic matter in karst dripwaters. Chem Geol 304-305:68-82. https://doi.org/10.1016 /j.chemgeo.2012.01.032

Herman EK, Toran L, White WB (2012) Clastic sediment transport and storage in fluviokarst aquifers: an essential component of karst hydrogeology. Carbonates Evaporites 27:211-241. https://doi.org/10.1007 /s13146-012-0112-7

Koeppenkastrop D, De Carlo E (1992) Sorption of rare-earth elements from seawater onto synthetic mineral particles: an experimental approach. Chem Geol 95:251-263

Laroche E, Petit F, Fournier M, Pawlak B (2010) Transport of antibiotic-resistant Escherichia coli in a public rural karst water supply. J Hydrol 392:12-21. https://doi.org/10.1016/j.jhydrol.2010.07.022

Laveuf C, Cornu S, Juillot F (2008) Rare earth elements as tracers of pedogenetic processes. C R Geosci 340:523-532. https://doi.org/10.1016/j.crte.2008.07.001

Laveuf C, Cornu S, Guilherme LRG, Guerin A, Juillot F (2012) The impact of redox conditions on the rare earth element signature of redoximorphic features in a soil sequence developed from limestone. Geoderma 170:25-38. https://doi.org/10.1016/j.geoderma.2011.10.014

Lee ES, Krothe NC (2001) A four-component mixing model for water in a karst terrain in south-central Indiana, USA: using solute concentration and stable isotopes as tracers. Chem Geol 179:129-143. https://doi.org/10.1016 /S0009-2541(01)00319-9

Lee ES, Krothe NC (2003) Delineating the karstic flow system in the Upper Lost River drainage basin, south central Indiana: using sulphate and $\delta 34$ SSO4 as tracers. Appl Geochem 18:145-153. https://doi.org/10.1016 /S0883-2927(02)00067-7

Mahler BJ, Lynch FL (1999) Muddy waters: temporal variation in sediment discharging from a karst spring. J Hydrol 214:165-178

Mahler BJ, Personné J-C, Lods GF, Drogue C (2000) Transport of free and particulate-associated bacteria in karst. J Hydrol 238:179-193. https://doi.org/10.1016/S0022-1694(00)00324-3

Massei N, Wang HQ, Dupont JP, Rodet J, Laignel B (2003) Assessment of direct transfer and resuspension of particles during turbid floods at a karstic spring. J Hydrol 275:109-121

Massei N, Dupont JP, Mahler BJ, Laignel B, Fournier M, Valdes D, Ogier S (2006) Investigating transport properties and turbidity dynamics of a karst aquifer using correlation, spectral, and wavelet analyses. J Hydrol 329:244-257 
Mayorga E, McDowell WH, Pinay G (2003) Biogeochemical hot spots and hot moments at the interface of terrestrial and aquatic ecosystems. Ecosystems 6:301-312. https://doi.org/10.1007/s10021-003-0161-9

McLennan S (1989) Rare earth elements in sedimentary rocks: influence of provenance and sedimentary processes. In: Geochemistry and mineralogy of rare earth elements. Mineral. Soc. Am., Washington, DC, pp 169-225

Morasch B (2013) Occurrence and dynamics of micropollutants in a karst aquifer. Environ Pollut 173:133-137. https://doi.org/10.1016/j.envpol.2012.10.014

Mudarra M, Andreo B, Baker A (2011) Characterisation of dissolved organic matter in karst spring waters using intrinsic fluorescence: relationship with infiltration processes. Sci Total Environ 409:3448-3462. https://doi.org /10.1016/j.scitotenv.2011.05.026

Mudarra M, Andreo B, Barberá JA, Mudry J (2014) Hydrochemical dynamics of TOC and NO3-contents as natural tracers of infiltration in karst aquifers. Environ Earth Sci 71:507-523

Pokrovsky OS, Manasypov RM, Loiko SV, Shirokova LS (2016) Organic and organo-mineral colloids in discontinuous permafrost zone. Geochim Cosmochim Acta 188:1-20. https://doi.org/10.1016/j.gca.2016.05.035

Pronk M, Goldscheider N, Zopfi J (2006) Dynamics and interaction of organic carbon, turbidity and bacteria in a karst aquifer system. Hydrogeol J 14:473-484

Pronk M, Goldscheider N, Zopfi J (2007) Particle-size distribution as indicator for fecal bacteria contamination of drinking water from karst springs. Environ Sci Technol 41:8400-8405

Pronk M, Goldscheider N, Zopfi J (2009) Microbial communities in karst groundwater and their potential use for biomonitoring. Hydrogeol J 17:37-48

Ryan M, Meiman J (1996) An examination of short-term variations in water quality at a karst spring in Kentucky. Groundwater 34:23-30. https://doi.org/10.1111/j.1745-6584.1996.tb01861.x

Shevenell L, McCarthy JF (2002) Effects of precipitation events on colloids in a karst aquifer. J Hydrol 255:50-68. https://doi.org/10.1016/S0022-1694(01)00510-8

Steinmann M, Stille P (1997) Rare earth element behavior and $\mathrm{Pb}, \mathrm{Sr}$, Nd isotope systematics in a heavy metal contaminated soil. Appl Geochem 12:607-623

Steinmann M, Stille P (2008) Controls on transport and fractionation of the rare earth elements in stream water of a mixed basaltic-granitic catchment basin (Massif Central, France). Chem Geol 254:1-18

Taylor SR, McLennan S (1985) The continental crust: its composition and evolution. Blackwell, Oxford, UK

Tepe N, Bau M (2014) Importance of nanoparticles and colloids from volcanic ash for riverine transport of trace elements to the ocean: evidence from glacial-fed rivers after the 2010 eruption of Eyjafjallajökull Volcano, Iceland. Sci Total Environ 488-489:243-251. https://doi.org/10.1016/j.scitotenv.2014.04.083

Tepe N, Bau M (2015) Distribution of rare earth elements and other high field strength elements in glacial meltwaters and sediments from the western Greenland Ice Sheet: evidence for different sources of particles and nanoparticles. Chem Geol 412:59-68. https://doi.org/10.1016/j.chemgeo.2015.07.026

Vermot-Desroches B (2015) Réalités du changement climatique en Franche-Comté du milieu du XIXe siècle à nos jours [Realities of the climate change in Franche-Comte from the XIXth century up to the present]. In: Histoire du climat en Franche-Comté. Éditions du Belvédère, Pontarlier, France

Vesper D, White W (2003a) Metal transport to karst springs during storm flow: an example from Fort Campbell, Kentucky/Tennessee, USA. J Hydrol 276:20-36. https://doi.org/10.1016/S0022-1694(03)00023-4 
Vesper D, White W (2003b) Spring and conduit sediments as storage reservoirs for heavy metals in karst aquifers. Environ Geol 45:481-493. https://doi.org/10.1007/s00254-003-0899-6

Vesper D, Loop C, White W (2001) Contaminant transport in karst aquifers. Theor Appl Karstology 13:101-111

White WB (2002) Karst hydrology: recent developments and open questions. Eng Geol 65:85-105

White WB, Vito C, Scheetz BE (2009) The mineralogy and trace element chemistry of black manganese oxide deposits from caves. J Cave Karst Stud 71:136-143

Zhou H, Wang Q, Zhao J, Zheng L, Guan H, Feng Y, Greig A (2008) Rare earth elements and yttrium in a stalagmite from central China and potential paleoclimatic implications. Palaeogeogr Palaeoclimatol Palaeoecol 270:128-138. https://doi.org/10.1016/j.palaeo.2008.09.001

Zhou H, Greig A, Tang J, You C-F, Yuan D, Tong X, Huang Y (2012) Rare earth element patterns in a Chinese stalagmite controlled by sources and scavenging from karst groundwater. Geochim Cosmochim Acta 83:1-18. https://doi.org/10.1016/j.gca.2011.12.027 